\title{
Renewable Energy Development in Indian Country: A Handbook for Tribes
}

\section{By Douglas C. MacCourt \\ Chair, Indian Law Practice \\ Ater Wynne LLP}

A Project for the National Renewable Energy Laboratory (NREL) and the Alliance for Sustainable Energy, LLC.

|une 2010 Edition 


\title{
RENEWABLE ENERGY DEVELOPMENT IN INDIAN COUNTRY: A HANDBOOK FOR TRIBES
}

\author{
A Project for the National Renewable Energy Laboratory \\ and the Alliance for Sustainable Energy, LLC \\ under Subcontract No. AEK-9-88294-01 \\ Technical monitor: Roger Taylor
}

\author{
BY DOUGLAS C. MACCOURT \\ CHAIR, INDIAN LAW PRACTICE GROUP \\ ATER WYNNE LLP
}

\begin{abstract}
EDITORS
DOUGLAS C. MACCOURT

JOHN M. SCHULTZ

CONTRIBUTING AUTHORS

L. DAVID CONNELL

ALICE CUPRILL COMAS

DOUGLAS C. MACCOURT

WILLIAM H. PRENTICE

ROB ROY SMITH
\end{abstract}

By Douglas C. MacCourt. All Rights Reserved.

Copyright 2010 by Douglas C. MacCourt and Ater Wynne LLP

\section{National Renewable Energy Laboratory}

1617 Cole Boulevard, Golden, Colorado 80401

303-275-3000 • www.nrel.gov

NREL is a national laboratory of the U.S. Department of Energy

Office of Energy Efficiency and Renewable Energy

Operated by the Alliance for Sustainable Energy, LLC

Contract No. DE-AC36-08GO28308 


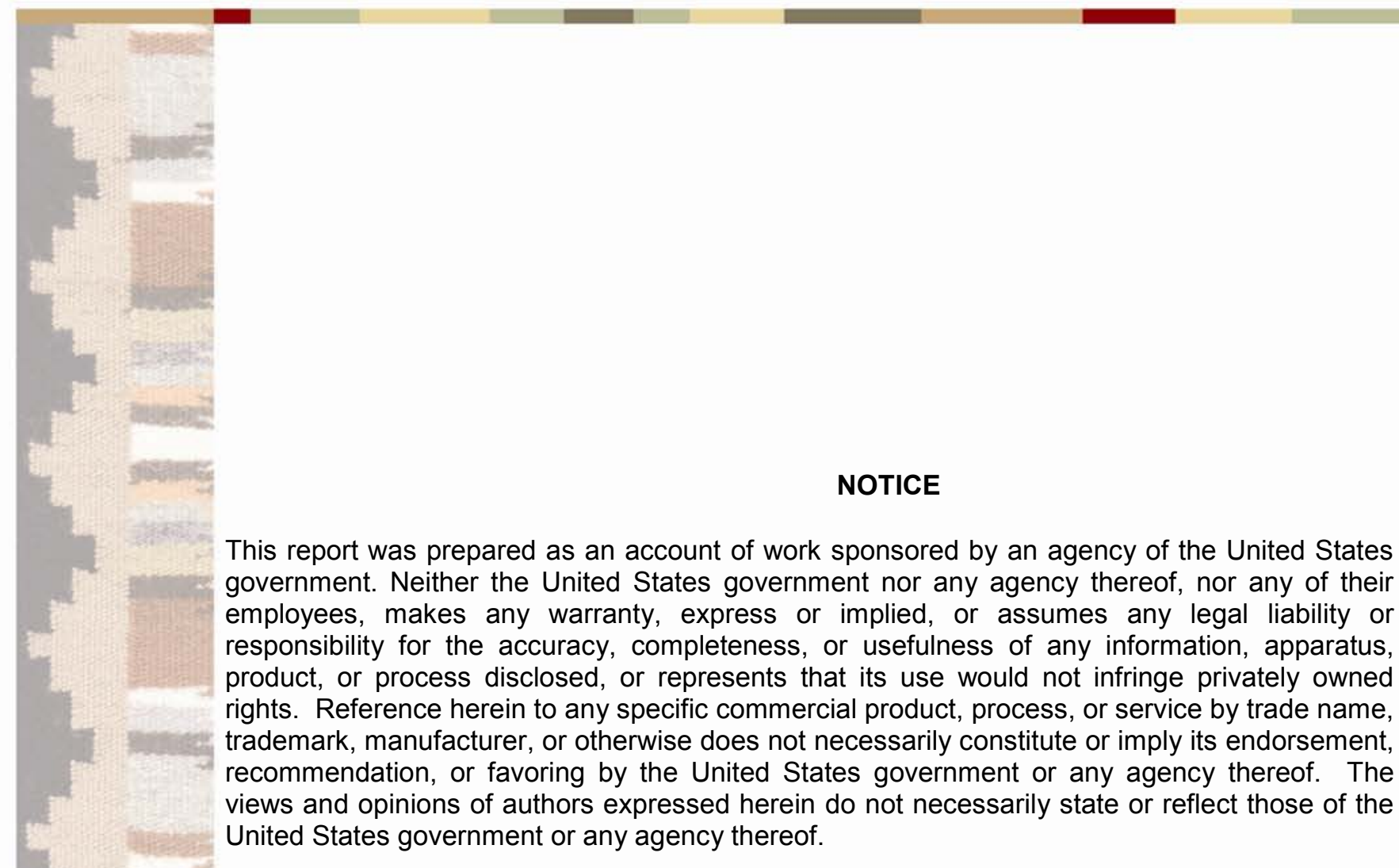

Available electronically at HTTP://WWW.OSTI.GOV/BRIDGE

Available for a processing fee to U.S. Department of Energy and its contractors, in paper, from:

U.S. Department of Energy

Office of Scientific and Technical Information

P.O. Box 62

Oak Ridge, TN 37831-0062

phone: 865.576 .8401

fax: 865.576 .5728

email: MAILTO:REPORTS@ADONIS.OSTI.GOV

Available for sale to the public, in paper, from:

U.S. Department of Commerce

National Technical Information Service

5285 Port Royal Road

Springfield, VA 22161

phone: 800.553 .6847

fax: 703.605 .6900

email: ORDERS@NTIS.FEDWORLD.GOV

online ordering: HTTP://WWW.NTIS.GOV/ORDERING.HTM 


\section{PREAMBLE}

\section{ORIGINS AND OBJECTIVES OF THIS HANDBOOK}

The concept for this Handbook grew out of presentations by Doug MacCourt of Ater Wynne LLP, at National Renewable Energy Laboratory (NREL) tribal energy workshops in Washington, D.C., Colorado, Alaska, California, New Mexico, South Dakota and Minnesota starting in 2007. Tribes and Alaska Natives participating in the NREL workshops sought a guide that would explain some of the key business and development issues encountered by tribes in energy projects. This guide builds upon the wealth of feedback and experiences shared by tribal and other participants in the NREL training sessions. It is offered as an accessible reference for those who are new to energy project development or seek a refresher on key development issues as they navigate the project development process.

To that end, this Handbook is intended to provide tribal leaders, tribal economic and energy enterprises and those supporting them with:

a general overview of the renewable energy project development process;

$>$ a discussion of how to structure a renewable energy project transaction to protect tribal interests, with an emphasis on joint project development efforts undertaken with nontribal parties;

a general overview of key energy development agreements, including power sale agreements, transmission and interconnection agreements, and land leases; and a detailed discussion of ways tribes can finance renewable energy projects, the sources of funding or financing that may be available, the types of investors that may be available, and federal tax incentives for renewable energy projects.

The Handbook is not a legal treatise. The target audience for this Handbook is tribal members and tribal government officials involved in energy development. There is also a 
glossary of some of the most commonly used technical terms that should be helpful for everyone new to this subject. The goal of the Handbook is to explain each subject in pragmatic and practical terms and to provide references to key resources for a more detailed treatment of technical or complex subject matters.

Of course, each tribe should consult with its legal representative(s) to determine how its particular circumstances are affected by the spectrum of tribal, state or federal laws and regulations that may apply to each project.

\section{FEEDBACK FROM TRIBES ON DRAFTS OF THIS HANDBOOK}

In April and June 2009, NREL hosted two tribal training sessions that reviewed and discussed earlier drafts of this Handbook. Based on feedback from the participants in those sessions, the Handbook was expanded to provide the following additional segments:

\footnotetext{
$>$ GREATER DETAIL ON THE ESSENTIAL ELEMENTS OF KEY ENERGY PROJECT AGREEMENTS;

A STRAIGHTFORWARD DISCUSSION ABOUT THE USE OF DEBT AND EQUITY IN ENERGY PROJECT TRANSACTIONS TO PROVIDE A FOUNDATION FOR THE HANDBOOK'S MORE DETAILED DISCUSSIONS OF FUNDING, FINANCIAL INCENTIVES, AND RELATED ISSUES;

$>$ INFORMATION ON NEW POLICIES AND FUNDING TOOLS CREATED BY THE OBAMA ADMINISTRATION THAT ARE AVAILABLE FOR TRIBAL RENEWABLE ENERGY DEVELOPMENT; AND
}

The Handbook is designed to be a living document that will continue to evolve and be supplemented over time. We welcome your feedback and comments. If you have any questions, comments or suggestions, please contact:

Douglas C. MacCourt, Chair, Indian Law Practice Group Ater Wynne LLP 1331 NW Lovejoy St., Suite 900

Portland, OR 97209

Email: dcm@aterwynne.com Phone: (503) 226-8672 or (503) 705-6031 (cell)

Fax: (503) 226-0079 


\section{RENEWABLE ENERGY DEVELOPMENT IN INDIAN COUNTRY: A HANDBOOK FOR TRIBES}

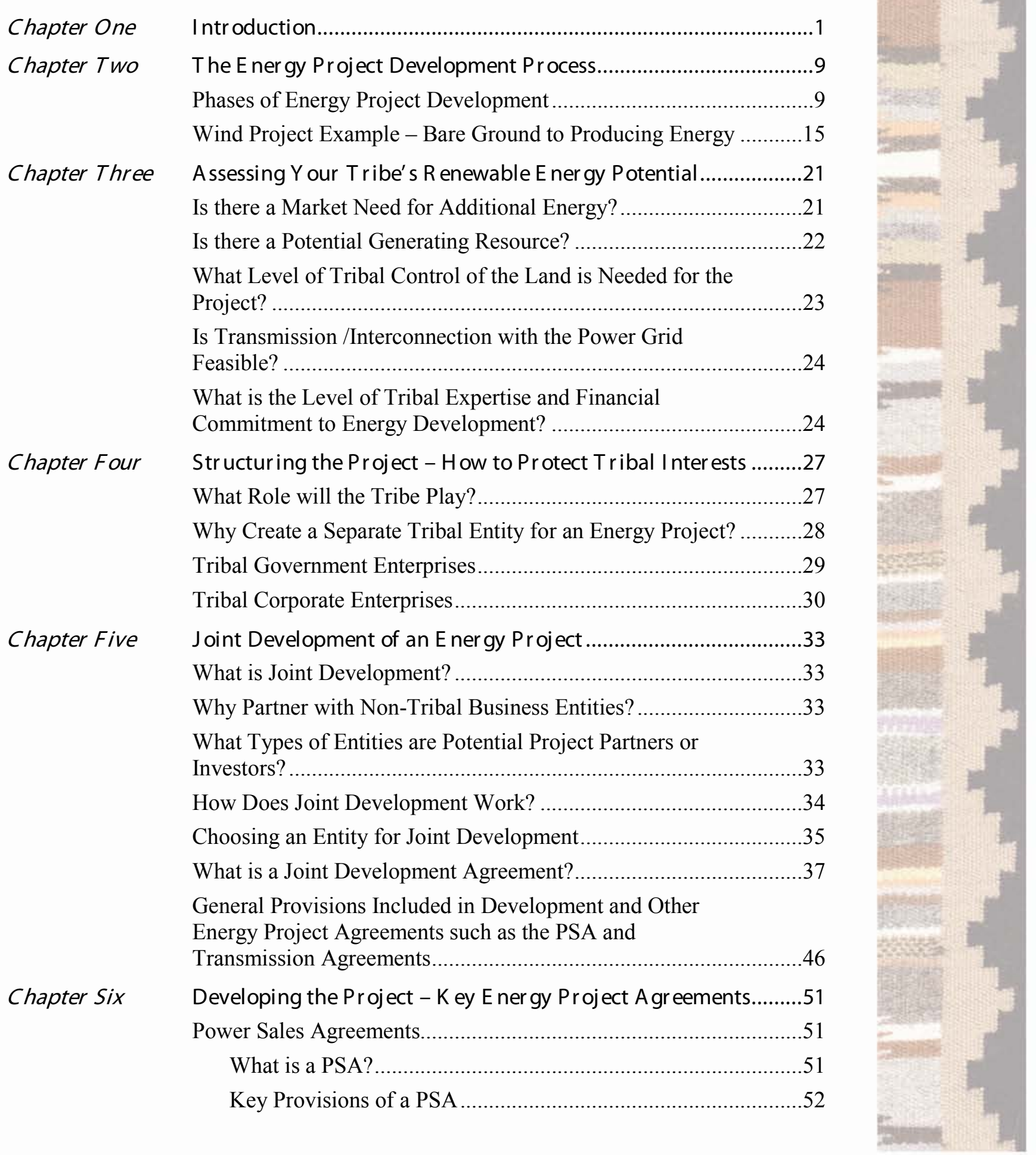




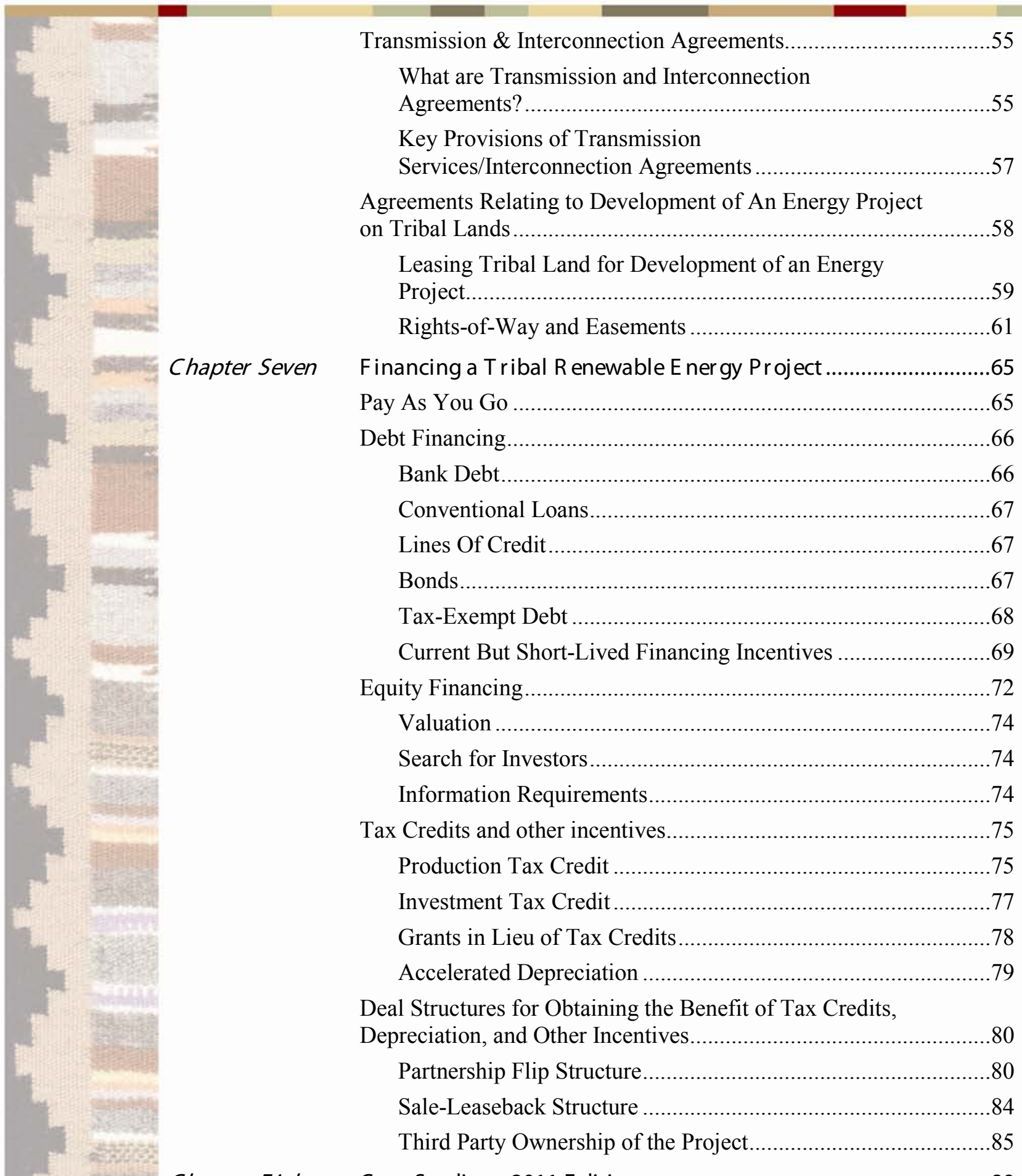

Chapter Eight $\quad$ Case Studies - 2011 E dition .........................................................89 


\section{INTRODUCTION}

Indian tribes and Alaska Natives in the United States (hereafter "tribes") are well positioned to take advantage of renewable energy development opportunities as a result of the vast amount of land and energy resources controlled by tribes. Tribes are actively exploring new business models to own and invest in energy assets, and to develop and produce power, either for consumption by their own people or for economic development purposes as a commodity for sale to utilities and industry on the wholesale power market. The goal of this Handbook is to provide tribal leaders and tribal members with concepts and strategies to assist them in understanding renewable energy project development, how best to protect tribal assets, preserve tribal sovereignty and, if the tribe chooses to do so, partner with nontribal entities for financing and project development. ${ }^{1}$

According to the United States Department of the Interior, the United States

While Indian country comprises only five percent of the land area of the United States, it contains an estimated ten percent of all energy resources in the United States. government currently holds approximately 55 million acres of land in trust for American Indians, Indian tribes and Alaska Natives. $^{2}$ Under the Alaska Native Claims Settlement Act (ANSCA), another 44 million acres have been set aside for Alaska Natives. ${ }^{3}$ The Bureau of Indian Affairs estimates that while Indian land comprises only five percent of the land area of the United States, it contains an estimated ten percent of all energy resources in the United States. ${ }^{4}$

Renewable energy potential in Indian country is even more significant. NREL has estimated that there is the potential for about 535 billion $\mathrm{kWh} /$ year of

\footnotetext{
${ }^{1}$ Due to the significant differences in the legal framework that governs Alaska native villages and corporations, this Handbook does not currently address the different legal issues faced by Alaska natives. Ater Wynne is preparing a separate handbook focused on energy development by Alaska native villages and corporations.

${ }^{2}$ United States Department of the Interior Bureau of Indian Affairs, What We Do, http://www.bia.gov/WhatWeDo/index.htm (last updated February 22, 2009).

${ }^{3}$ Felix Cohen, Cohen's Handbook of Federal Indian Law 965 (2005 ed.).

${ }^{4}$ DOE Office of Energy Efficiency and Renewable Energy (EERE), DOE's Tribal Energy Program, PowerPoint Presentation prepared by Lizana K. Pierce available at http://apps1.eere.energy.gov/tribalenergy/.
} 
wind energy alone available on Indian lands in the contiguous 48 states, which is equivalent to 14 percent of current U.S. total annual energy generation. NREL estimates that there is also 17,600 billion $\mathrm{kWh}$ /year of solar energy potential on Indian lands in the lower 48 states; this amount is equivalent to 4.5 times the total U.S. electric generation in $2004 .^{5}$ In addition, Indian Country will continue to play a growing role in transmission infrastructure throughout the nation.

Many tribes are already involved in energy development. The Tribal Energy Program of the United States Department of Energy (DOE) ${ }^{6}$ participated in funding 93 tribal energy projects between 2002 and 2008 and the number continues to rise. Of these 93 projects, 34 were in the "planning and prefeasibility stage," 51 were performing "feasibility studies," and eight were proceeded to "development and demonstration" Several tribes have developed commercial scale wind projects and others are in the process of developing commercial scale biomass and solar projects.

In addition to the significant tribal control of land and resources in the U.S. and the national focus on renewable energy, tribal interest in renewable energy projects will also likely be fueled by each tribe's long-term goals relating to sovereignty, sustainability, and financial security. In Indian country the past decade has brought with it a renewed focus on tribal selfdetermination, with tribes asserting more control over their land, resources and self-governance. Renewable energy may support a wide range of tribal economic activities, from tourism and gaming to manufacturing and telecommunications. Many tribes have also begun to experiment with their unique legal status to accelerate their economic development efforts. Energy development is one way tribes are creating the infrastructure and capacity to achieve

The top ten states for installed wind power capacity are: Texas, Iowa California, Washington, Minnesota, Oregon, Illinois, New York, Colorado, and North Dakota. economic independence.

\footnotetext{
${ }^{5} I d$.

${ }^{6}$ See http://apps1.eere.energy.gov/tribalenergy/.
} 


\section{CURRENT TRENDS IN RENEWABLE ENERGY}

\section{RAPID GROWTH}

More than $\$ 120$ billion was invested in new renewable energy capacity world-wide in 2008 (almost double the estimated $\$ 63$ million invested in 2006). ${ }^{7}$ Most of this increase reflected investments in wind power (42 percent) and solar photovoltaic installations (32 percent), followed by smaller shares in biomass power, geothermal and small hydropower projects. ${ }^{8}$ In 2008, renewable energy capacity reached an estimated 280 gigawatts worldwide, an increase of more than 50 percent over 2004.

In 2009, the U.S. wind energy industry shattered all previous records by installing 9,922 megawatts (MW) of new generating capacity - enough to serve over 2.4 million homes if operating at full capacity around the clock) - more than doubling the nation's total wind power generating capacity the nation had in

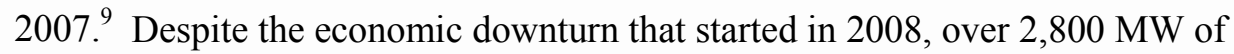
new wind generating capacity was installed in the United States in the first quarter of $2009 .^{10}$

Wind is not the only renewable energy resource experiencing a significant increase in available capacity. Solar projects have also added significant additional capacity in certain regions during the same period, primarily in the Western states.

Solar generating facilities using photovoltaic panels installed 5,400 MW of capacity worldwide in 2008, up an estimated 50 percent over $2007 .{ }^{11}$ At the end of 2008, cumulative global installed solar generating capacity stood at 12,950 MW, enough to power 2.4 million homes under optimal conditions. Solar power

\footnotetext{
${ }^{7}$ REN21.2009.Renewables Global Status Report 2009 Update (Paris: REN21Secretariat) at 14. ${ }^{8} \mathrm{Id}$.

${ }^{9}$ American Wind Energy Association, U.S. Wind Energy Industry Breaks All Records, Installs Nearly 10,000MW in 2009, Press Release (January 26, 2010) available at http://www.awea.org.

${ }^{10}$ American Wind Energy Association, U.S. Wind Energy Industry Installs Over 2,800 MW in First Quarter, Press Release (April 28, 2009) available at http://www.awea.org.

${ }^{11}$ REN21.2009.Renewables Global Status Report 2009 Update (Paris: REN21Secretariat) at 24.
} 
generating capacity has grown by an average of 48 percent each year since 2002 because of the increased efficiency and lower production costs of solar panels. These improvements have made the cost of solar power more cost competitive with other renewable resources. ${ }^{12}$

\title{
RENEWABLE PORTFOLIO STANDARDS
}

President Barack Obama was elected to office in 2008 on a campaign platform that included a commitment to create a new, clean energy economy. In keeping with that platform, the Obama administration is promoting a national goal of producing ten percent of our energy from renewable sources by 2012 and 25 percent by 2025. At least 30 states have adopted renewable portfolio standards (RPS) for many larger utilities. An RPS requires that a percentage of the power that an electric utility sells to its customers come from renewable sources. Most

An RPS requires a percentage of an electric provider's energy sales (MWh) or installed capacity $(M W)$ to come from renewable sources. states have mandated minimum percentages that increase incrementally from a base year to an ultimate year, e.g. in Oregon the mandate is five percent by 2011, 15 percent by 2015,20 percent by 2020 and 25 percent by $2025 .{ }^{13}$

\section{THE "SMART GRID"}

Congress set forth the first national statement of a "smart grid" policy in the Energy Independence and Security Act (EISA) of 2007:

\begin{abstract}
"It is the policy of the United States to support the modernization of the Nation's electricity transmission and distribution system to maintain a reliable and secure electricity infrastructure that can meet future demand growth and to achieve each of the following
\end{abstract}

\footnotetext{
${ }^{12}$ Jonathon G. Dorn, Earth Policy Institute, Solar Cell Production Jumps 50 Percent in 2007 (December 27, 2007) available at http://www.earth-policy.org/Indicators/Solar/2007.html.

${ }^{13}$ See DOE Office of Energy Efficiency and Renewable Energy, States with Renewable Portfolio Standards (May 2009) available at http://apps1.eere.energy.gov/states/maps/renewable_portfolio_states.cfm.
} 
[specific technology goals] which together characterize a Smart Grid." $" 14$

Essentially, the term "smart grid" refers to an information-rich electrical grid that allows the entire system - from loads in homes and businesses to power plants - to be operated more efficiently. A key element of this new grid will be its capability to exchange data with the end user's equipment and to react to conditions on the grid system rather than just function as a one-way delivery conduit. Smart grid policy recognizes that new measures and technology should be incorporated throughout the grid by energy generators (the supply side), within the transmission and

A "smart grid" is a more efficient and information rich electrical grid infrastructure.

Some of the key attributes are:

the use of "smart" meters for time-of-day billing and to facilitate demand-side energy management efforts by utility customers; increasing the grid's efficiency in delivering power from all types of generating resources; and

making it more cost effective to deliver power between regions to more effectively balance consumer loads and generating resources.

distribution infrastructure (the delivery infrastructure), and by end users of energy (the demand side). ${ }^{15}$ Both the EISA and more recently, the American Recovery and Reinvestment Act of 2009 (ARRA), provide funding opportunities for smart grid projects and activities.

Many industry experts agree that improvements to our nation's transmission infrastructure will be critical to the future of renewable energy development. An effort is underway to develop a more extensive high-voltage interstate transmission system connecting new projects to distant wholesale power

\footnotetext{
${ }^{14}$ See Title XIII of the Energy Independence and Security Act of 2007 (EISA 2007), codified at 15 U.S.C. 17381 et seq.; $\S \S 1223$ and 1241 of the Energy Policy Act of 2005 (EPA Act 2005) ( $\$ 1241$ is codified at $\S 219$ of Part II of the Federal Power Act (FPA) (16 U.S.C. 824 et seq.)).

${ }^{15}$ US Department of Energy, Office of Electricity Delivery and Energy Reliability, The Smart Grid: an Introduction available at http://www.oe.energy.gov/smartgrid.htm.
} 
markets. Stakeholders are also working to streamline the federal approvals and processes required for siting and construction of transmission lines. ${ }^{16}$

\section{Project FinanCing: TAX CREDITS AND NEW InCENTIVES}

In order to spur development of renewable energy projects Congress has developed a number of legislative incentives. Over the past decade, one of the primary federal incentives for renewable energy development has been in the form of tax credits. Congress has also provided for accelerated depreciation deductions with respect to renewable energy project costs. Historically, the majority of renewable energy projects were financed, in part, by

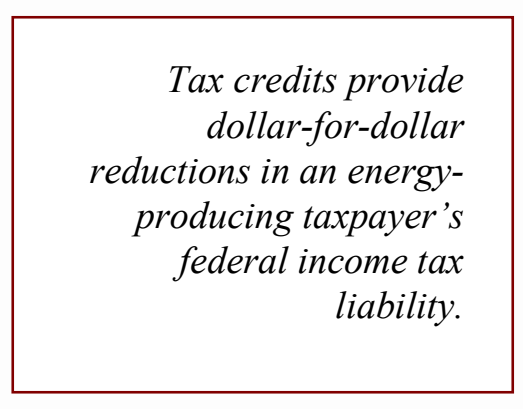
large banks and other investors with an appetite for tax credits and accelerated depreciation (i.e., their investment was motivated by and partially in exchange for the tax credits and accelerated depreciation).

However, with the 2008-2009 U.S. financial system problems there are fewer institutional investors seeking tax credits and depreciation deductions. Lenders have also significantly limited funding for project development. Participants in the renewable energy industry have proposed legislative changes that range from making unusable tax credits refundable, to providing an option to "carry back" unused tax benefits for up to 10 years (resulting in a refund of past taxes paid), to allowing for the ability to trade tax credits (entities that cannot use tax credits can trade or sell them to entities that can). Congress is also evaluating alternatives for many of the tax incentives that are limited or unavailable for taxexempt entities, including tribal governments. This is discussed in more detail in Chapter Seven.

In response to new financing sources and a changing market, some tribes are turning to new project development models, including the formation of taxable

\footnotetext{
${ }^{16}$ See American Wind Energy Association, Wind Power Outlook 2009, available at http://www.awea.org. See also United States Department of the Interior, Nine Federal Agencies Enter into a Memorandum of Understanding Regarding Transmission Siting on Federal Lands, Press Release (October 28, 2009).
} 
tribal business entities to capture the value of these incentives. It is possible that new federal legislation will change the project financing environment such that Indian tribes would not be at a disadvantage in developing renewable energy projects. Congress has partially addressed this issue by permitting Indian tribes to issue clean renewable energy bonds and other debt instruments for renewable energy projects. ${ }^{17}$ The American Recovery and Reinvestment Act of 2009 included some short-term tax benefits, such as a limited term cash grant in lieu of tax credits for certain projects. ${ }^{18}$ The Act also extends investment tax credits to wind, geothermal and biomass energy projects and earmarked billions of dollars for smart grid initiatives. ${ }^{19}$ These and other financial tools for tribes are discussed in Chapter Seven.

\footnotetext{
${ }^{17}$ Senator Tim Johnson of South Dakota (D) has introduced a bill that, if passed, would encourage joint partnerships between private investors and tribes by allowing tribes to transfer Production Tax Credits to private joint partners on renewable energy projects. See "Highlights Importance of Tribal PTC Transfer Bill," Press Release from Office of Senator Johnson (April 9, 2009).

18 American Recovery and Reinvestment Act of 2009, Pub. L. No. 111-5 (February 17, 2009). As discussed in Chapter Seven, cash grants in lieu of tax credits are not available to projects owned by any federal, state, or local government, including an Indian tribal government, a taxexempt organization described in IRC $\S 501(\mathrm{c})$, or any partnership or other pass-through entity of which any of the foregoing is a partner or holder of an equity interest. Guidance from the U.S. Treasury Department provides that this limitation can be avoided by owning and operating the project through a taxable corporation.

${ }^{19}$ Id.
} 


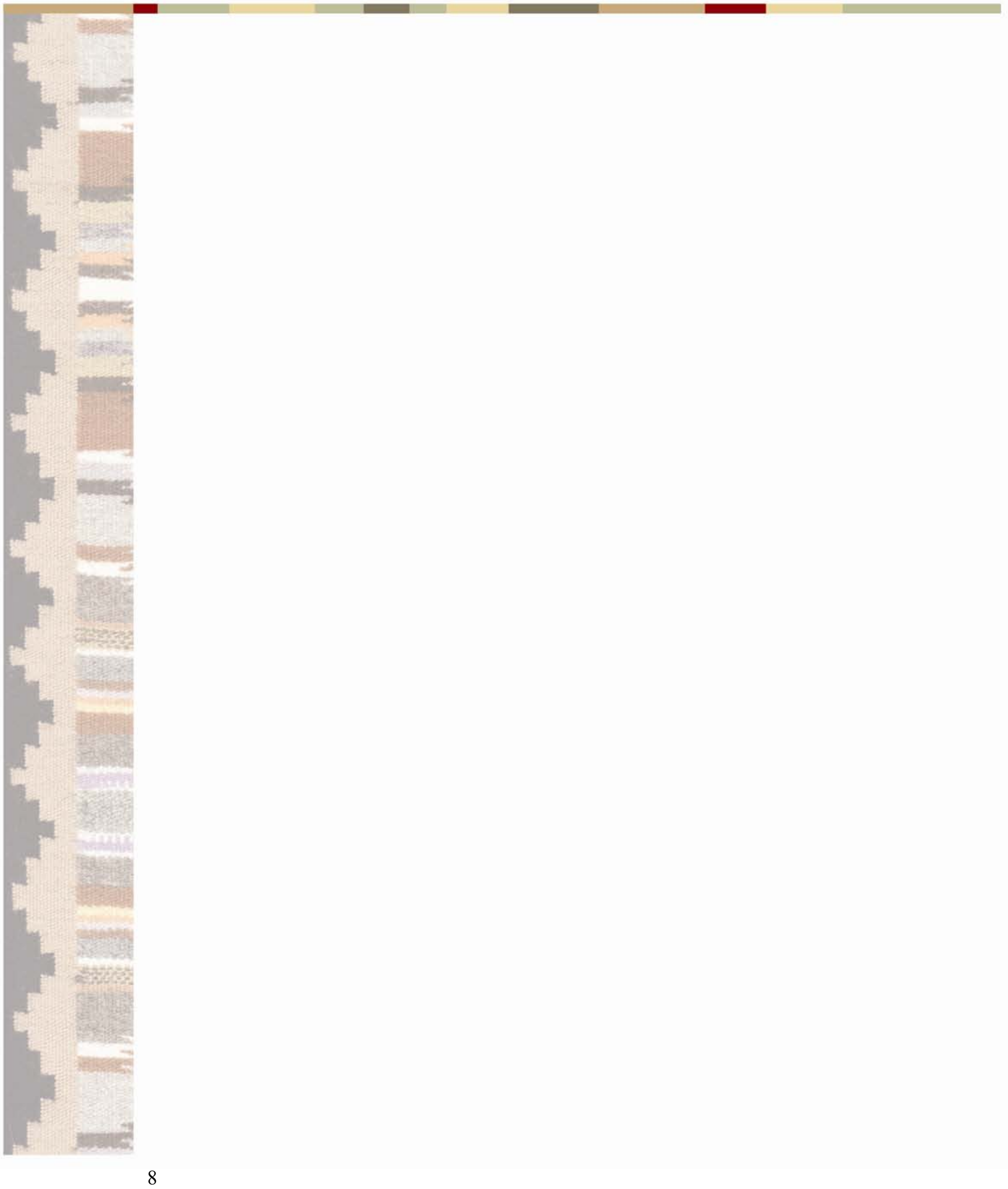


Development of any energy project is almost always a complex and longterm process that requires the involvement of many people and typically costs many millions of dollars over the course of several years. While the exact development path of each project is unique, it is helpful to think of the energy development process in terms of certain development "phases" that most energy projects experience. The following discussion provides a general overview of the phases generally encountered in energy project development. In any particular project, the tasks involved in these phases may be combined, rearranged or modified to fit the tribe's and the project's needs.

\section{Phases of ENERGy PROJeCt DEVEL opment}

Phase One: At the earliest phase of project development a preliminary feasibility assessment or "fatal flaw" analysis is prepared, reviewing key aspects of energy development in its market area (e.g., demand for power, potential generating resources, availability of cost-effective interconnection with the power grid, control of potential project sites, tribal capacity and tribal government support for carrying out a project, and potential partnering and financing opportunities with tribal, non-tribal and government entities).

Phase Two: After identifying one or more potential energy projects, reviewing the results of the fatal flaw analysis and confirming tribal capacity and support, the tribe then considers all key aspects of each proposed project. This scoping stage generally results in a decision on whether there is a potentially viable project and whether to move forward with it. At this time, the tribe may consider proposals from outside project developers who would undertake some or all phases of development. ${ }^{20}$

Phase Three: Load and transmission studies and preliminary engineering designs are completed. Discussions with likely customers take place regarding electric load requirements and potential terms.

\footnotetext{
${ }^{20}$ As discussed in greater detail in Chapter Four, a tribe may choose to play a passive role or an active role, or to enter into a joint venture with a developer of a project. For simplicity, this Handbook uses the term "developer" to refer to the entity that is leading development of a project, though that entity might be tribal, non-tribal, or a joint venture.
} 
Phase Four: At the fourth and critical phase of development, the essential elements needed to allow construction of the project must be secured. This includes obtaining necessary permits, licenses and approvals (such as National Environmental Policy Act (NEPA) review and Endangered Species Act (ESA) consultation), to executing transmission and power sales agreements and obtaining necessary financial commitments.

Phase Five: With money and permits in hand, the construction and commissioning or startup of the project can begin.

Phase Six: The completed and commissioned project begins commercial operation with ongoing maintenance.

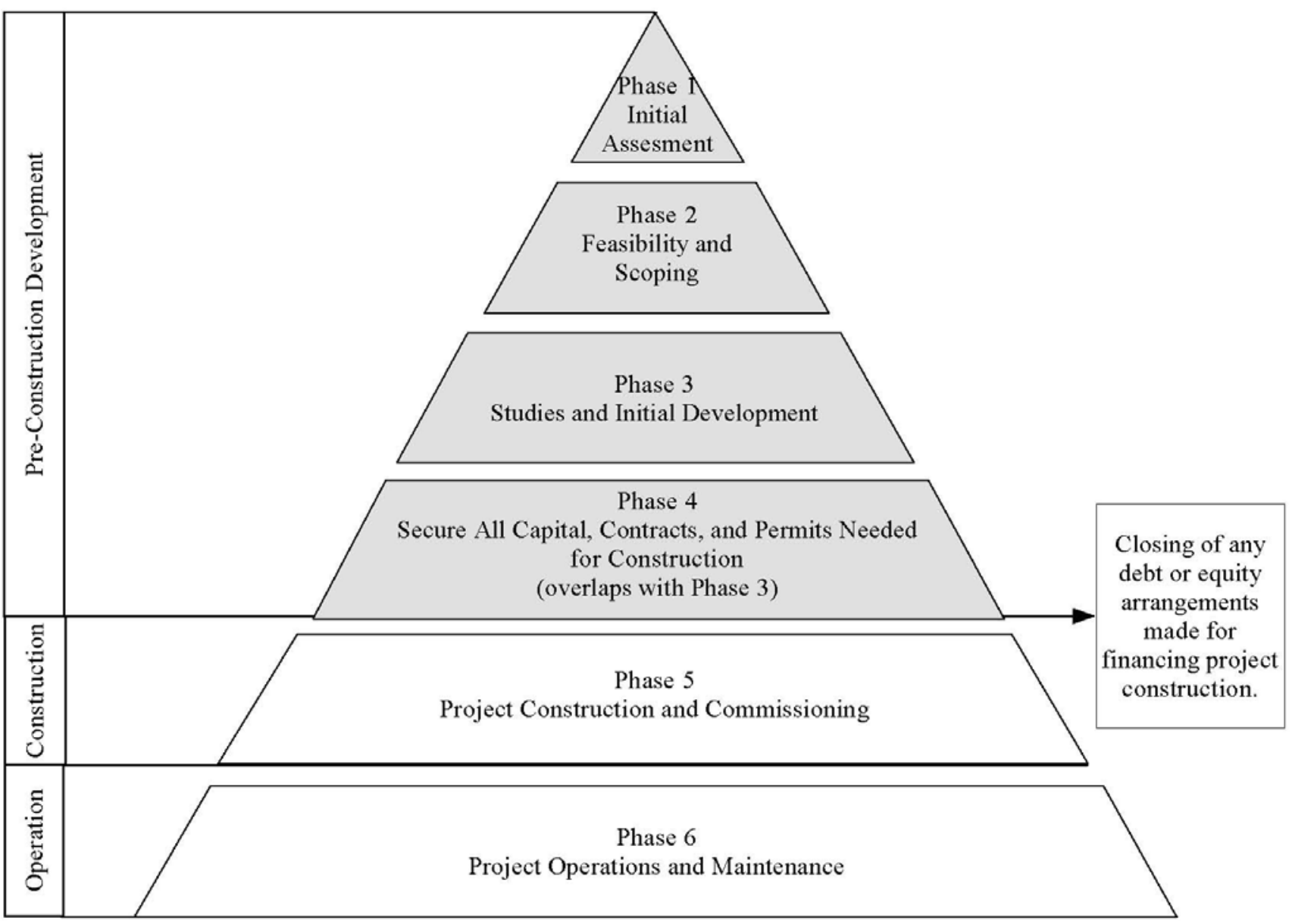


The energy project development process can be thought of in terms of several distinct but overlapping development phases. At each phase, a developer must take steps relating to each of the following components:

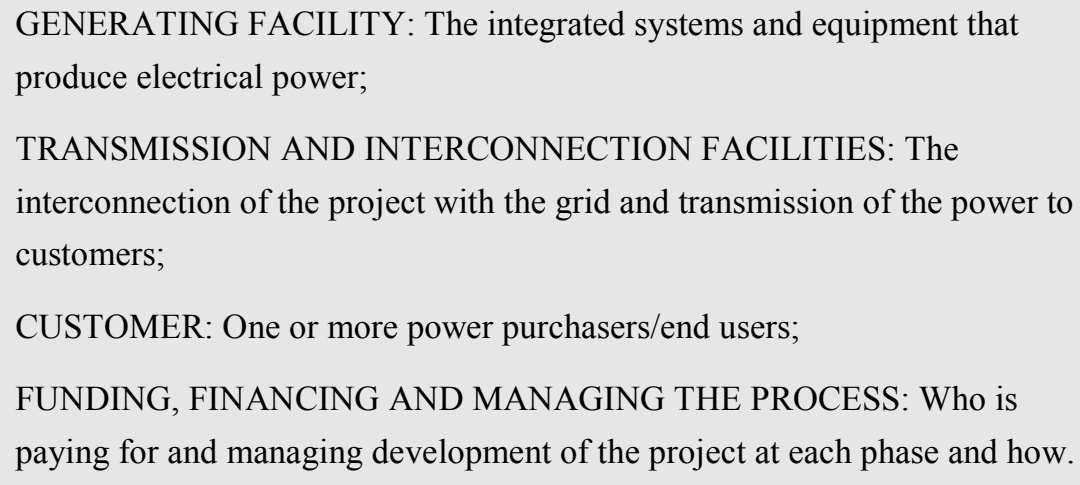

The following paragraphs focus on each of the four components identified in the above box and provide an overview of the issues involved with respect to each component during each phase of project development.

\section{GENERATING FACILITY: (PHASES ONE THROUGH SIX)}

The generating facility is the heart of the project. During phase one of a project the developer identifies potential sites for the generating facility, which will include evaluating available resources (wind, biomass, solar, geothermal, hydro, etc.). Even at this early stage it is important for the tribe to create a budget for evaluating the potential energy project or projects. During phase two the developer must make an initial determination regarding the preferred scale of the project and the potential market for output from the project. As the project moves forward into feasibility studies and initial project development, the developer will need to secure initial property rights or site control before construction of the generating facility. For a project on tribal trust land, securing a potential site may involve a lease from the tribe to the developer. For a wind project, the developer will need to erect meteorological towers to collect wind data for two years or more. The developer will also need to engage a consultant to analyze and model the data. 
In the final phase of pre-construction development the developer must finalize project specifications and design, finalize property rights for project construction and secure any tribal, state or federal permits necessary for construction of the generating facility. At this point in the development of a project the developer will need to decide whether it will accomplish construction of the generating facility through an Engineering, Procurement and Construction (EPC) agreement or by acting as the general contractor and managing the many subcontracts. If acting as a general contractor, the developer must begin sourcing and procuring the major equipment required for construction of the generating facility.

\section{TRANSMISSION AND INTERCONNECTION: (PHASES ONE THROUGH SIX)}

During the initial assessment phase the developer will evaluate whether interconnection with the power grid is possible from potential generating facility sites. Next, during the feasibility and scoping phase, the developer will carefully identify and study the interconnection options to determine which would be the most cost-effective way to connect to the electric grid. If development of the project moves forward to phase three, the tribal sponsor will usually pay the proposed transmission provider to undertake a transmission system study that will determine if sufficient capacity is available on the system, identify any construction requirements, and specify the requirements for project equipment to interconnect with the grid. At the final pre-construction phase the developer will secure a final transmission services agreement and transmission interconnection agreement. These agreements are discussed in greater detail in Chapter Six.

\section{CUSTOMER: (PHASES ONE THROUGH SIX)}

If the initial assessment results in a determination that there is a market need for the project's anticipated output, the developer will next focus on identifying specific potential buyers for the output. By the time the developer has begun the initial pre-construction development activities for the generating facility and transmission/interconnection, the developer should also begin discussing some basic terms (MWh power delivery expectations, price, etc.) with one or more potential customers. At the final pre-construction development phase, the project 
developer will likely need to finalize at least one substantial Power Sales

Agreement in order to secure financing for construction.

FUNDING, FINANCING AND MANAGING THE PROCESS: (PHASES ONE THROUGH SIX)

Unless the tribe has been approached by an outside developer, the tribe will most likely pay for and manage all aspects of the initial assessment stage. The tribe should be aware that while the cost and associated risk is comparatively minimal at this stage, it is still important to budget realistically. During phases two and three of pre-construction development, project information may be developed that dictates a halt in development of the project or results in significant changes. If the project continues to move forward the tribe will need to realistically assess how it will pay for and manage the pre-construction development of the project. In some circumstances, a tribe may determine that it can pay for or finance pre-construction development on its own. Alternatively, the tribe may decide to solicit proposals from potential project partners

The budget and expenditures at the final phase of pre-construction development of a project will increase significantly as time and money are spent securing permits as well as negotiating the transmission, interconnection and power sales agreements. or investors. For example, a tribe contemplating a commercial wind project may identify a strategic partner with extensive experience managing development of wind projects. In that case, the exact nature of the parties' respective financial obligations and management responsibilities should be clearly set forth in the parties' agreement for joint development (discussed in detail in Chapter Five).

Before beginning the final pre-construction phase of securing contracts, permits and financing, the project developer should step back and reexamine the prudence of doing the project. The budget and expenditures at the final phase of pre-construction development of a project will increase significantly as time and money are spent securing permits as well as negotiating the transmission, interconnection and power sales agreements. During the fourth and final phase of pre-construction development, the project developer should have well formulated 
plans for funding and financing actual construction of the project, and the lenders and investors should be involved in most aspects of at least the final phase. For example, a lender may have specific requirements as to the terms for dispersal of funds for construction. Additionally, both debt and equity sources of funding will likely require some sort of assurance of an adequate cash flow from which the project can make its debt payments. The assurance is, in most cases, provided by the signed power sales agreement which sets forth the terms and conditions for the sale of the power delivered by the project. If the project developer enters into an EPC arrangement, that contract should represent the guaranteed maximum price of the project. If the tribe is acting as the general contractor, it most likely will need to have secured subcontracts for all components of the project and demonstrate that it can complete the project with the funds available to it. Project lenders will want to confirm that all necessary arrangements are in place and will be appropriately managed in order to deliver the project on time and within its budget.
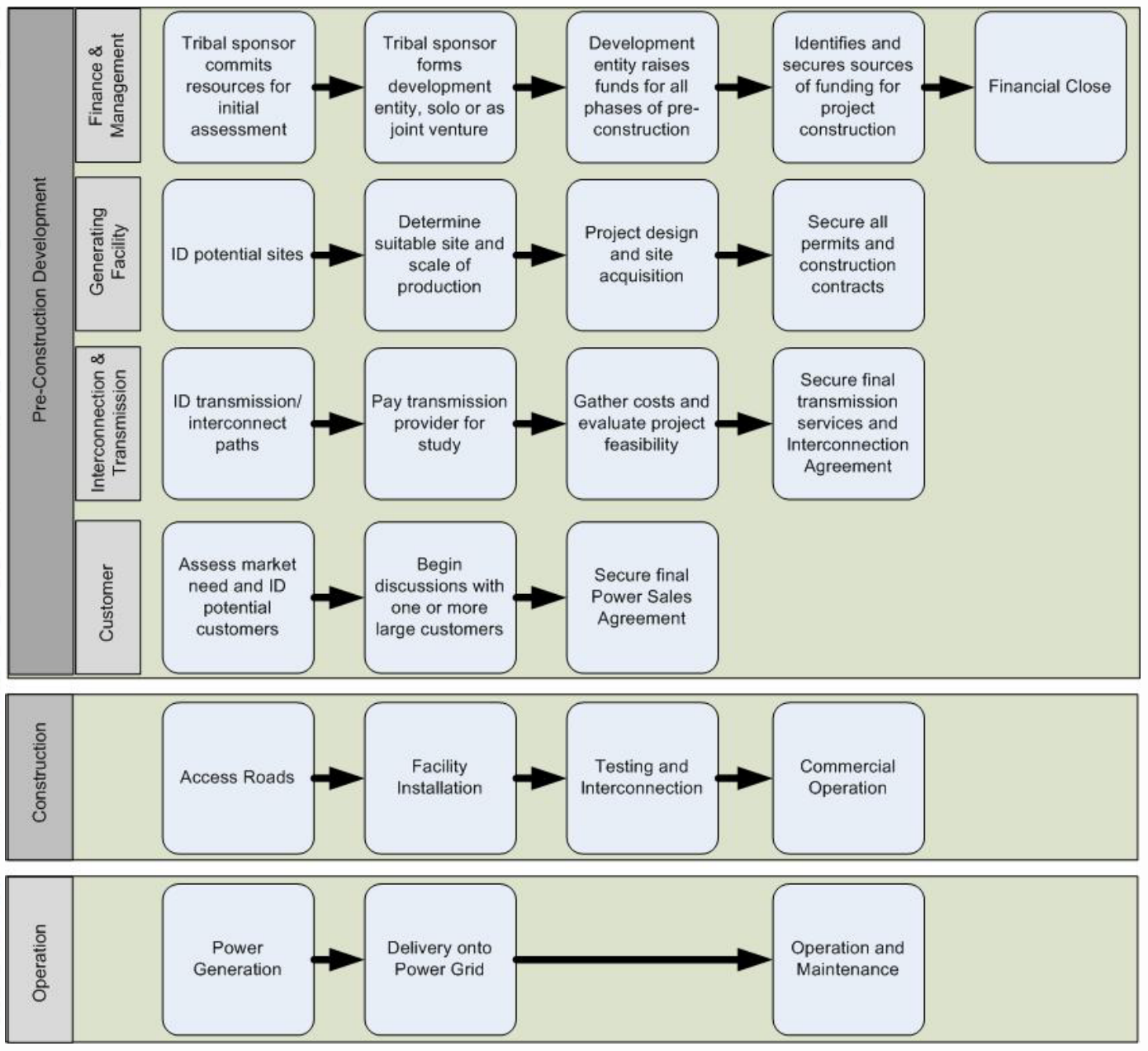
The development of a wind project is different than a biomass, geothermal or hydro resource because of the project's footprint and the number of turbines usually involved. A utility-scale wind project requires relatively large tracts of land that are often located in remote areas, which can make assessment, construction and operation particularly challenging. (Some of these considerations would also apply to solar projects.)

The viability of a wind project is very dependent upon its location. It must be built where the best wind resource is available, which might be far from roads, transmission lines and other essential infrastructure. The costs of bringing this infrastructure to the project site may make the site economically unsuitable even if it has a good wind resource. Determining these costs and their likely effect on what the project would have to charge for its power is essential prior to committing the effort and resources to continued development activities. Even if a site is not currently economically viable, the tribe may want to consider keeping an option on it if it has a good wind resource, but suspend development until the necessary infrastructure is in place.

One of the first critical issues is to determine the availability of transmission service to the proposed site, both in the physical distance from existing mainline transmission facilities and determining whether there is sufficient capacity in those existing facilities to transport the project's output. The transmission provider will require a study to determine whether transmission service to the project is feasible and to estimate the cost to serve the proposed project. The cost of the study is paid by the developer pursuant to an agreement, the form of which may be dictated by the transmission provider's tariff or regulators. The developer may also have to construct interconnection facilities to the transmission provider's specifications. There may be a queue for receiving transmission service, which generally requires a deposit and application in order to reserve a place in the line. Providers add capacity in block increments and want to have an increment heavily subscribed before they undertake construction. The queue and an applicant's position in the queue help determine the need for the next 
increment of transmission capacity and who has a priority to access the new increment of transmission capacity.

The next step is for the tribe and, if applicable, the non-tribal developer, to reach agreement on the terms and conditions for rights on the property needed for the project. ${ }^{21}$ Because the precise amount of land needed may not be known prior to the completion of due diligence activities, the agreement may include an option between the developer and the tribe to allow for assessment of the wind resource and other development activities. The term or length of such an option will typically run three to five years. Each option agreement should also include a right to lease the property if the project goes forward, as well as to temporarily use any other property for the construction stage. The agreement will also set the initial term of the lease following project completion, which typically is at least twenty to twenty-five years with further options for renewal. The developer typically will want to secure all the necessary rights in the initial approach to the landowner in order to be certain of the availability of the property if the project does go forward.

Any agreement to have access to and use land should also allow for extensions at each stage of the development process, which generally will require an additional payment to the landowner. An extension is preferable in order to allow delays to be absorbed without forcing a decision to either move on to the next step or abandon the project before all of the necessary analysis and preparatory work is complete. At each point in the development of the project, the agreement generally would provide for an additional payment to the landowner as the option is either extended or the project moves on to the subsequent step. Once the project is operational, the landowner typically receives a royalty payment for the energy produced by the project, depending upon the structure of the deal.

The development of roads on and to the site is another important task. The turbine parts and other equipment are generally transferred to the site by truck and many of the loads will be very long, very heavy or both. Whether the roads are

${ }^{21}$ Depending on the business structure of the project and ownership status of the land, the tribe may be the landowner, the developer, or both. 
public or private, the project almost always will be required to fund any necessary road improvements or construction required to allow safe delivery of the project components. The assessment process must include an estimate of the cost to acquire any necessary rights and land, as well as the cost to construct needed improvements and/or new roads. Roads on the site must be constructed to accommodate the large cranes and other equipment required both for project construction and for the maintenance of the project after commercial operation is achieved.

Once rights to the land are secured and the infrastructure costs are estimated, then the next task is to assess the wind resource. Assessing the adequacy of the wind resource requires that meteorological data be collected from the proposed site, preferably for at least two years. The equipment and towers that support the equipment will have to be acquired through lease or purchase. This data is essential to making critical decisions about the project. First of all, it is used to determine the suitability of the site from the perspective of the available wind resource. If the resource is viable, the data is then used to choose the type of turbines to be employed and determine their placement on the property. There are experienced vendors that will do the necessary analysis and modeling. It is very important to choose a vendor that has the confidence of the project lenders as this analysis will be a critical piece of the project lenders' underwriting process.

If the developer determines that the site is viable, then the agreements for construction of the project must be negotiated. Separate arrangements must be made for sourcing and procuring the turbines and balance of plant equipment and for construction work to prepare the site and build the project. The equipment and towers that support the equipment typically will have to be acquired through lease or purchase. Some equipment may have long lead times for delivery, which must be coordinated with the construction schedule. Construction can be accomplished through individual contracts or through a comprehensive EPC agreement with a single provider. There are advantages and disadvantages to each approach. Using a series of contracts may allow for more control over the pricing and terms of each segment of construction, but this approach carries with it the risks associated with 
coordinating and scheduling the activities and vendors. If a project uses a series of contracts, it will be especially important to have an experienced construction supervisor or project manager in place. If the EPC path is chosen and a satisfactory vendor engaged, the project can be constructed on a turnkey basis. A disadvantage of this approach is that it can be more expensive since the EPC vendor will include some price coverage for its assumption of the risk.

The next essential agreement is a power sales agreement (PSA), which is explained in detail in Chapter Six. It will be essential to have this agreement finalized relatively early in the process if the project is to be financed. Project financiers will look for a term of power sales at least as long as that of their loan for the project. Wind projects can often get a premium for their output since it is "green." Renewable energy credits (RECs) for such green energy, which serve to monetize the green nature of the energy, can be sold with the power or separately, depending upon the requirements of the customer. The modeling for the wind resource figures in here as well. As discussed in Chapter Seven, some wind projects may be eligible for federal production tax credits (PTC) or investment tax credits (ITC) or a grant in lieu of the applicable credits. Investors with a tax appetite can take advantage of these credits by taking an ownership position in the project that "flips" to a minority ownership position once they have achieved their desired financial return or by means of other structures discussed in more detail in Chapter 7. The terms of these agreements are usually very complex and must meet federal tax requirements, which means it is mandatory that any developer doing this type of transaction engage legal advisors with expertise in this type of transaction. It will be very important to have these advisors in place even during the preliminary discussions with potential counterparties.

\section{A transmission services agreement and transmission interconnection} agreement will be required to get the project's output to the ultimate customer. Those agreements are also explained in more detail in Chapter Six. There is likely to be much less negotiation over the precise terms and condition of the transmission service agreement since the transmission services will almost certainly be provided pursuant to a tariff or regulations that require that all 
customers be served on equal terms. The primary issues will be whether there is enough available capacity to provide the project's requested transmission service; who will fund and construct the interconnection facilities; and what level of credit support will be required from the party receiving transmission service. Since there may be a queue for obtaining service, this agreement must be pursued early in the development process to allow time for studies to be performed, equipment specified, and capacity verified. It is important to note that a project might not be able to obtain transmission service within its preferred time constraints and/or the project might have to construct a connecting transmission line at its own expense in order to obtain transmission service.

Once the project is operational, it must be both operated and maintained. Much of the work related to operating the project requires skilled personnel to maintain and repair the turbines and supporting equipment, and to manage the power sales operation. The major equipment such as the turbines will have an initial warranty period under which any major work generally will be the responsibility of the manufacturer. If one of the project goals is to provide employment opportunities to the community, during this initial warranty period project personnel may receive training through the manufacturer and then assume responsibility for these tasks. It is very important to have someone knowledgeable managing the power sales contract and ensuring that the agreements with landowners and service providers are properly administered.

\section{CONCLUSION}

As illustrated by the wind project example above, energy project development is a complex process that involves working on several issues concurrently during all phases of pre-construction development. This Handbook uses the phases of pre-construction development identified above as a roadmap. Now the Handbook will examine the following issues and examples:

Chapter Three provides a general overview of "Assessing Your Tribe's Renewable Energy Potential." 


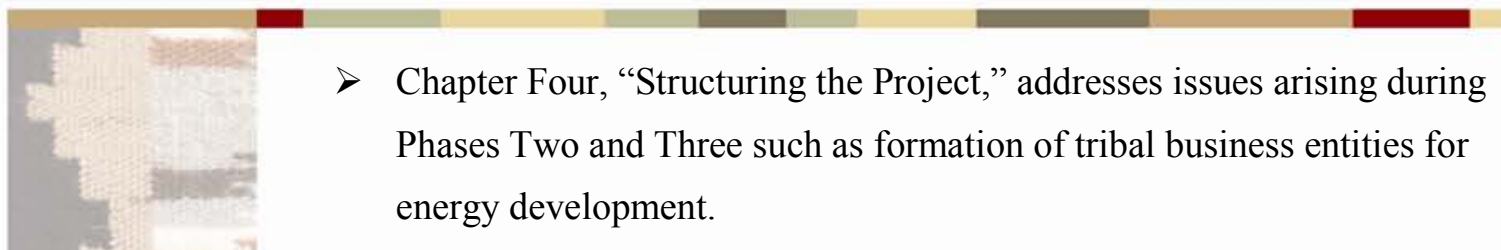

Chapter Five is a detailed discussion of "Joint Development of an Energy Project."

Chapter Six looks at key energy agreements likely to be required during phase four of developing an energy project.

Chapter Seven focuses on financing construction of a project.

Chapter Eight, to be published in 2011, will provide case studies of several tribal renewable energy projects and lessons learned. 


\section{ASSESSING Y OUR TRIBE'S RENEWABLE ENERGY POTENTIAL}

Whether your tribe has been approached by an energy developer with a project proposal or your tribe is interested in independently developing its own project, a thorough assessment is an important initial step of the development process for a successful energy project. As noted earlier, many tribes are already undertaking energy resource assessments. DOE's Tribal Energy Program has provided financial support for a number of tribes to undertake general strategic energy planning. The Tribal Energy Program has also provided funding for tribes to engage in feasibility studies for biomass, geothermal, solar, wind and multiple resource energy projects. $^{22}$

The DOE Tribal Energy Program has developed a "Guide to Tribal Energy Development" (DOE's Guide) that has thorough and informative sections devoted to "Strategic Energy Planning" and "Evaluating Options.",3 The DOE's Guide provides information about the relative costs of renewable energy technology options, how to prepare a project feasibility study for an energy project, and much more. We recommend consulting the DOE's Guide and energy consultants for assistance with your tribe's preliminary assessments.

\section{IS there a Market NeEd for Additional Energy?}

One of the critical decisions a tribe must make in the planning stages is whether the project will furnish power to tribal customers and facilities only or produce energy for sale to others. If the tribe wishes to serve wholesale electricity demand, it is critical to analyze the energy market that could be served by the output from a tribal energy project. Does the local or regional electric utility need additional supplies? Is there a large commercial or industrial user that would be willing to enter into a long-term contract for the purchase of power? These are the types of questions that a tribe should consider in evaluating the market.

While there are a few tribal utility authorities that own and operate utility facilities and provide utility services to tribal members, most tribes are served by

\footnotetext{
${ }^{22}$ See DOE Tribal Energy Program, "Projects by Tribe" and "Projects by Type of Technology" available at http://apps1.eere.energy.gov/tribalenergy/projects.

${ }^{23}$ DOE's "Guide to Tribal Energy Development" is available at http://apps1.eere.energy.gov/tribalenergy/guide.
} 
one or more non-tribal investor-owned public utilities or cooperatives. At least one study shows that the electric transmission and distribution lines on reservations are generally inadequate for existing demand not to mention load growth or the additional needs of a power project. This inadequacy of electric transmission and distribution lines on reservations often leads to higher electricity rates and reduced reliability. ${ }^{24}$ Meanwhile, the United States Census Bureau has estimated that tribal populations will nearly double in the next fifty years and could reach 4.4 million, with the fastest-growing segment of tribal populations aged 30 and under. ${ }^{25}$ These statistics suggest that there is or likely will be a market need for additional power and transmission infrastructure within tribal communities.

\section{IS THERE A POTENTIAL GeneRATING RESOURCE?}

There are many energy generating resources that renew naturally: biomass, wind, solar, hydro and geothermal heat to name a few. Renewable resource availability is highly localized and the resource varies greatly with geography.

It is important to recognize that the cost-effectiveness of a renewable energy project depends upon whether the cost of developing the renewable power source is less (or not unacceptably more) than the cost of an available conventional resource. In many cases, the expense of building transmission from the renewable resource to the main power grid may tip the balance against the viability of a renewable energy project.

Experienced energy consultants and the tribe's legal counsel can assist in this evaluation. Tribes can also consult with NREL for data regarding renewable energy resource potential in their particular geographical area.

\footnotetext{
${ }^{24}$ A March 2000 study commissioned by the U.S. Department of Energy revealed that $14.2 \%$ of Indians households on reservations had no access to electricity, compared to only $1.4 \%$ of all U.S. households. The study also demonstrated that Indian households spend a greater portion of their annual income on electricity.

${ }^{25}$ United States Census Bureau, National Population Projections (released 2008, based on 2000 Census), available at WWW.CENSUS.GOV/POPULATION/WWW/PROJECTIONS.
} 
What LEVEL of Tribal Control of the LAND is NeEded for the PROJECT?

Assessment of potential energy development requires a careful look at the ownership status and suitability of land that would be required for development of a project. As outlined in the introduction, many tribes already have control of land and potential generating resources suitable for energy development. For many tribes, the primary considerations at this point will likely involve evaluating internal political support for development of a particular parcel or generating resource, as well as assessing issues that may arise from the long-term presence of non-tribal entities on trust land.

With respect to power generation it is important to consider the land resource needs of particular generating resources. Wind and solar projects both require large areas or footprints, while certain fossil fuel (e.g., coal, natural gas) projects typically require less land but also have environmental considerations and need secure sources of water for use in cooling systems. At this assessment stage tribes should identify key legal agreements that might be required, such as leasing land to or from a third party. Additionally, tribes should begin to identify the federal, state and tribal approvals that might be required for project development. Examples of such approvals include fish and wildlife agency review for threatened or endangered animals and plants; cultural resource surveys and approvals from tribal and federal agencies; and air and water quality permits. State and local land use and project siting requirements are not likely to apply to projects based solely on tribal land, but if the project includes private, non-tribal land or other state lands, state laws may apply. Decisions by the BIA regarding the leasing or use of tribal trust land or other decisions by federal agencies (e.g. such as allowing transmission line rights-of-way) can trigger a National Environmental Policy Act review. Such a review could lead to a time-consuming environmental assessment and/or the need to go through an environmental impact statement process for the entire project.

As a tribe assesses a potential renewable energy project, it should identify any potentially significant obstacles to development on or near a particular land 
parcel. Assessing a potential project's access to transmission involves determining the proposed project's proximity to a mainline transmission line and other necessary infrastructure. As part of its analysis, the tribe should also assess the current road and rail access to the project site and begin to identify any related key legal agreements that might be required, such as rights-of-way and easements.

\section{Is TRANSmission / NTERCONNECTION WITH THE POWER GRID FEASIBLE?}

This is a critical part of assessing an energy project because costeffectiveness of the project may depend upon access to transmission. In almost every case, the challenge is to find good sites where transmission can be accessed with limited additional expense. This expense could be incurred either to increase capacity on the transmission system to accommodate the project's output or as a result of the distance between the project and an interconnection point. The project almost certainly will have to bear the expense of constructing a line between the project and interconnection point, or for new substation facilities to access existing lines.

The transmission component of a project may also require separate agency approvals, permits, legal agreements and resolution of environmental issues depending on whether a project requires construction of new transmission facilities or not.

\section{WHAT IS THE LEVEL OF TRIBAL EXPERTISE AND FINANCIAL COMMITMENT TO} ENERGY DEVELOPMENT?

Every energy project requires a team to support the tribe and its project with engineering, financial, legal, political and public relations expertise. Tribes should begin by assessing the level of expertise available to the tribe for pursuit of an energy project prior to commencing project-related activities. Some of the most critical expertise required for development of a project includes:

Project development skills (including the ability to perform the initial research and analysis, determine the type of project, prepare the business case for developing it and secure financing necessary to construct the project); 
Legal (project contracts, permits and transaction structuring, regulatory proceedings and process);

Land use (permits, threatened and endangered plants and animals);

Environmental (air emission restrictions and project mitigation, Endangered Species Act consultation, water quality and water rights);

$>$ Engineering (design project and manage construction);

$>$ Project management (both during construction and operation);

Contract management (construction agreements, equipment procurement, power sales agreement, transmission agreement and agreements with land owners); and

$>$ Government Relations (appropriations, grants and public support).

Even a comparatively small project can be very complex to develop and not everyone with a proposal has the experience, means or ability to implement that proposal. Experts and advisors should be chosen based upon their success in the type of project the tribe wants to pursue, as well as their compatibility with the priorities and processes of the developer and tribe.

Additionally, pre-construction project development requires substantial financial commitment even at early stages (site selection, resource analysis, preliminary designs, negotiating critical agreements). During the later phases of pre-construction development, funding is often required for one or more of the following: securing land rights (purchase, lease, license, easements, etc.); engineering (design, sourcing, procurement and construction services); securing transmission system capacity rights; and negotiating and securing a long-term power sales agreement. 

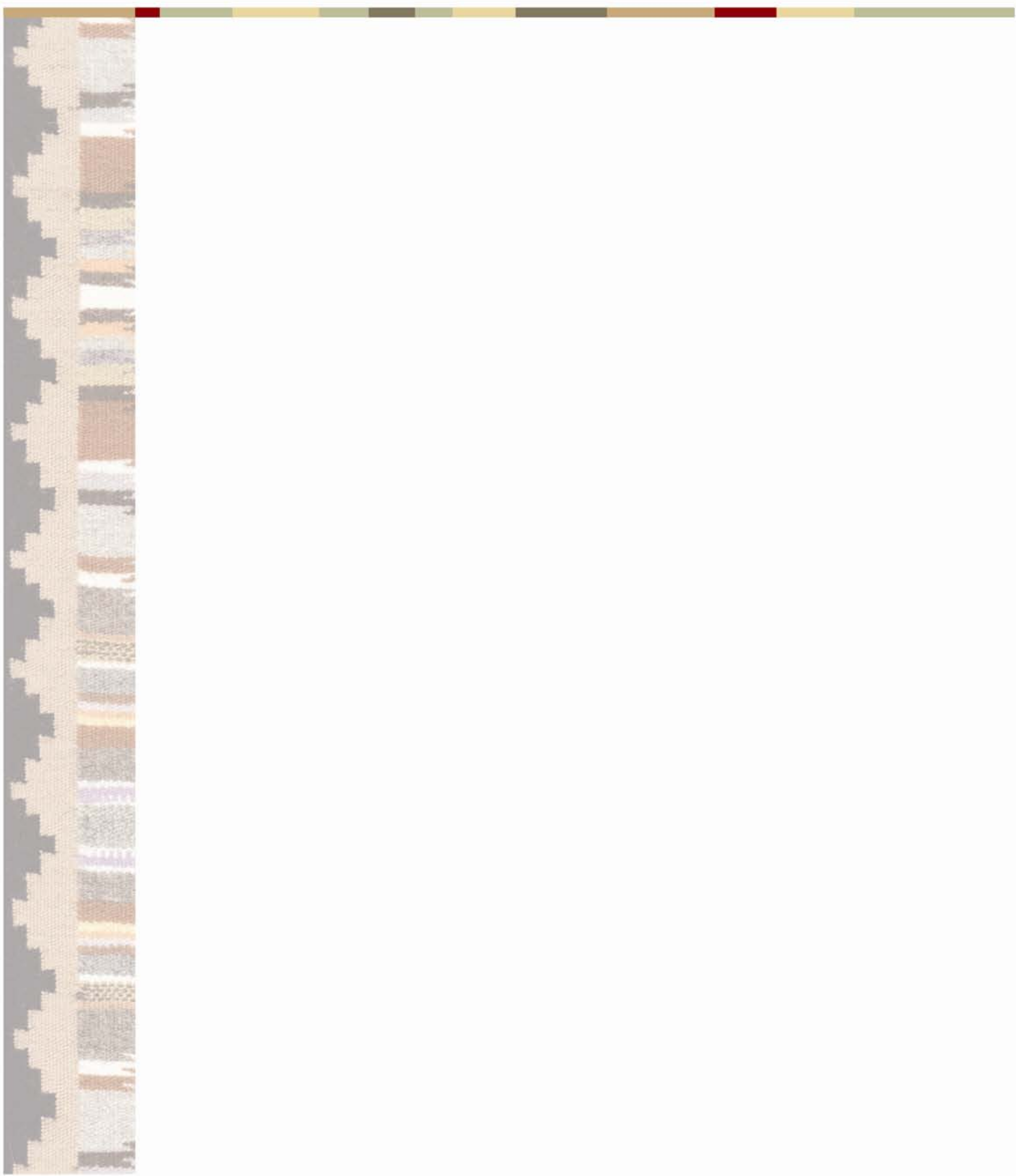
The energy project development process can be both complex and lengthy. Because of that, how your tribe chooses to carry out development of an energy project can impact the tribe's financial and energy independence, and could have implications for tribal sovereignty. It is therefore worthwhile for tribes to very carefully consider the tax, liability, and control consequences of the various business entities available to tribes.

\section{What ROLE WILL THE TRIBE PLAY?}

A threshold issue for many tribes contemplating development of an energy project is whether to play a passive or active role. Often, the tribe's role may ultimately be dictated by the tribe's need to partner with third parties. Some energy projects may only be economically viable if the project is owned by a non-tribal entity that can get the full benefit of tax credits and accelerated depreciation.

Tribes must decide early in the process whether they want a long-term role in the management, operation and ownership of an energy project or simply want to collect revenues. The decision requires thorough and

Tribes must decide early in the process whether they want a long-term role in the management, operation and ownership of an energy project or simply want to collect revenues. The decision requires thorough and early evaluation and there is no single right answer. early evaluation, and there is no single right answer.

\section{PASSIVE Role}

A tribe may choose to be a passive player in energy development, by simply leasing its land to a third party who develops, constructs and operates the energy project. Even if the tribe remains an owner/operator of a project, it may contract out the entire project to a developer with proven experience in financing, designing, and constructing the type of project under consideration. Tribes may elect to play a passive role initially and then hire experienced management to train tribal members to take over responsibility for some or all of the development and operation of its energy projects. A passive role can also be employed simply to move the project along faster. On the down side, a tribe playing a completely 
passive role may potentially lose the opportunity to develop internal experience or take advantage of certain management or investment opportunities.

\section{ACTIVE ROLE}

When a tribe chooses to play an active role in energy development, it usually acts as developer or general contractor and manages all aspects of development of the project. When a tribe develops, owns and operates all aspects of a project, it retains direct control over the project and makes a strong commitment to tribal autonomy. It also keeps more of the money and experience within the tribe. However, undertaking the project alone may not be the best decision for many tribes. The greater the control exerted or retained by the tribe usually increases the financial and other project risks to the tribe. Tribes with limited resources and without significant energy project experience or other critical skill sets may find their interests best served by shifting or sharing the management and financial risks of a project to an outside party, at least for the tribe's first projects.

\section{SOMEWHERE IN BETWEEN - JOINT DEVELOPMENT}

Because there are downsides to both the passive and active roles, many tribes are drawn to the possibility of entering into a joint development agreement with a third-party to co-develop a project. We discuss joint development of an energy project in Chapter Five.

\section{Why Create a Separate Tribal Entity for an Energy Project?}

As sovereign governments tribes have a unique bundle of privileges and immunities. Whether a tribe plans to play a passive or active role in project development or enter into joint development of a project, it is important to carefully consider the different types of tribal business structures that are available and select the most appropriate option.

There are a number of reasons most tribes should establish a separate entity for any kind of energy development project. Energy projects are long-term, 
complicated projects that involve raising money, managing construction and managing long-term operations. An energy project needs a dedicated team with expertise and authority to make decisions. In determining the best business structure for a given energy project, a tribe must determine which structure will best achieve its multiple goals of securing investors and financing, maintaining control and sovereign independence, and protecting the tribe from liability.

\section{TRIBAL BUSINESS ENTERPRISES}

There are two main categories of tribal business enterprises: a tribal government enterprise and a tribal corporate enterprise. This section provides an overview of both types and highlights the advantages and disadvantages of each type.

\section{TRIBAL GOVERNMENT ENTERPRISES}

\section{THE TRIBE}

Because a tribe enjoys full privileges and immunities (sovereign immunity, exemption from income tax, ability to issue tax-exempt bonds), a tribe itself can undertake a business venture. However, energy development undertaken by the tribe may expose tribal assets to liabilities incurred in connection with the energy project. Additionally, tribal leadership may have less experience with energy development, and decisions and timing relating to the project may be susceptible to the delays associated with any political process.

\section{AN ENTERPRISE AGENCY OR INSTRUMENTALITY OF THE TRIBE}

A separate unit of government formed by statute or ordinance may still be controlled by tribal council, but often has a separate board of directors and management team. Tribal agencies or instrumentalities are easy to form, enjoy sovereign immunity (unless and to the extent it is waived), and are exempt from federal income tax. However, agencies or instrumentalities of a tribe are still essentially units of tribal government and may not be able to secure certain types of financing. For example, equity financing by outside investors is not possible for a wholly-owned tribal agency or instrumentality. Debt financing options need to be 
carefully explored, as the availability of tax-exempt debt or bank loans will vary depending on the nature of the project and the assets available for collateral.

\section{A Political SUbdivision of the TRIBE}

A tribe may establish a political subdivision by fully delegating one of its sovereign powers to a separate government entity. Formation of a political subdivision requires both BIA and IRS confirmation, but it can carry with it substantial benefits. A political subdivision of a tribe is exempt from federal income tax, retains sovereign immunity, and may issue tax-exempt bonds. ${ }^{26}$ However, a political subdivision may be constrained by its delegated powers and duties and may be less flexible than a tribal corporate entity. In addition, some business partners or lenders involved in a project may be wary of dealing with a political subdivision.

\section{TRIBAL CORPORATE ENTERPRISES}

\section{SECTION 17 CORPORATION}

Tribes can form corporations under Section 17 of the Indian Reorganization Act of $1934 .^{27}$ Formation of a Section 17 corporation requires a tribal resolution, followed by tribal approval of the corporate charter, and BIA ratification of the corporate charter. Like the tribal government entities, the corporation must be wholly owned by a tribe, which precludes equity ownership by outside investors. However, since the assets of a Section 17 corporation can be pledged as collateral, it may more easily secure debt financing for a project. Additionally, such corporations are exempt from federal income tax and may issue tax-exempt bonds. Unlike political subdivisions, the assets and liabilities of a Section 17 corporation are wholly separate from the assets and liabilities of the tribe. A Section 17 corporation can be sued in its corporate form, but the tribe itself can retain sovereign immunity. Additionally, Section 17 corporations have

${ }^{26}$ See Felix Cohen, Cohen's Handbook of Federal Indian Law 1283-1284 (2005 ed.).

${ }^{27} 25$ U.S.C. $\S 477$. 
25-year leasing authority and under 25 U.S.C. $\S 81$, approval of leases/contracts by the BIA is not required. ${ }^{28}$

\section{TRIBALLY-CHARTERED CORPORATION}

Another corporate entity available to tribes is a corporation chartered under tribal law. ${ }^{29}$ A tribally-chartered and tribally-owned corporation can be formed by tribal ordinance or by using a tribal corporation code, and has the benefit of achieving separation of corporate assets and liabilities from tribal assets and liabilities. The financing options for a tribally-chartered corporation likely include loans, taxable bond issuances, or debt from a commercial lender. However, in order to secure adequate financing, the tribally-chartered corporation may be required to waive sovereign immunity. Another issue for a tribally-chartered corporation is that the tax status of these corporations is uncertain. A corporation chartered under tribal law may be subject to federal income tax.

\section{STATE-CHARTERED CORPORATION}

A state law corporation is relatively easy to form and also achieves full separation of tribal assets and liabilities from corporate assets and liabilities. Financing options for a state law corporation are likely to include loans, taxable bond issuances or debt financing from a commercial lender. However, a state law corporation is subject to federal income tax, may not issue tax-exempt debt, probably cannot assert sovereign immunity to suit (depending on state law) and will be subject to state reporting requirements and other state laws.

\section{STATE-CHARTERED LIMITED LIABILITY COMPANY (LLC)}

State law LLCs are easy to form under state law and, like corporations, LLCs achieve full separation of tribal assets and liabilities from LLC assets and liabilities. The LLC structure is familiar to lenders and potential business partners and LLC members obtain the tax benefits of a pass-through entity. If a tribe is the sole member of an LLC, the LLC should enjoy tribal tax-exempt status; however,

\footnotetext{
${ }^{28}$ Cohen, Federal Indian Law at 1284.
}

${ }^{29}$ Id. at $1284-1285$. 


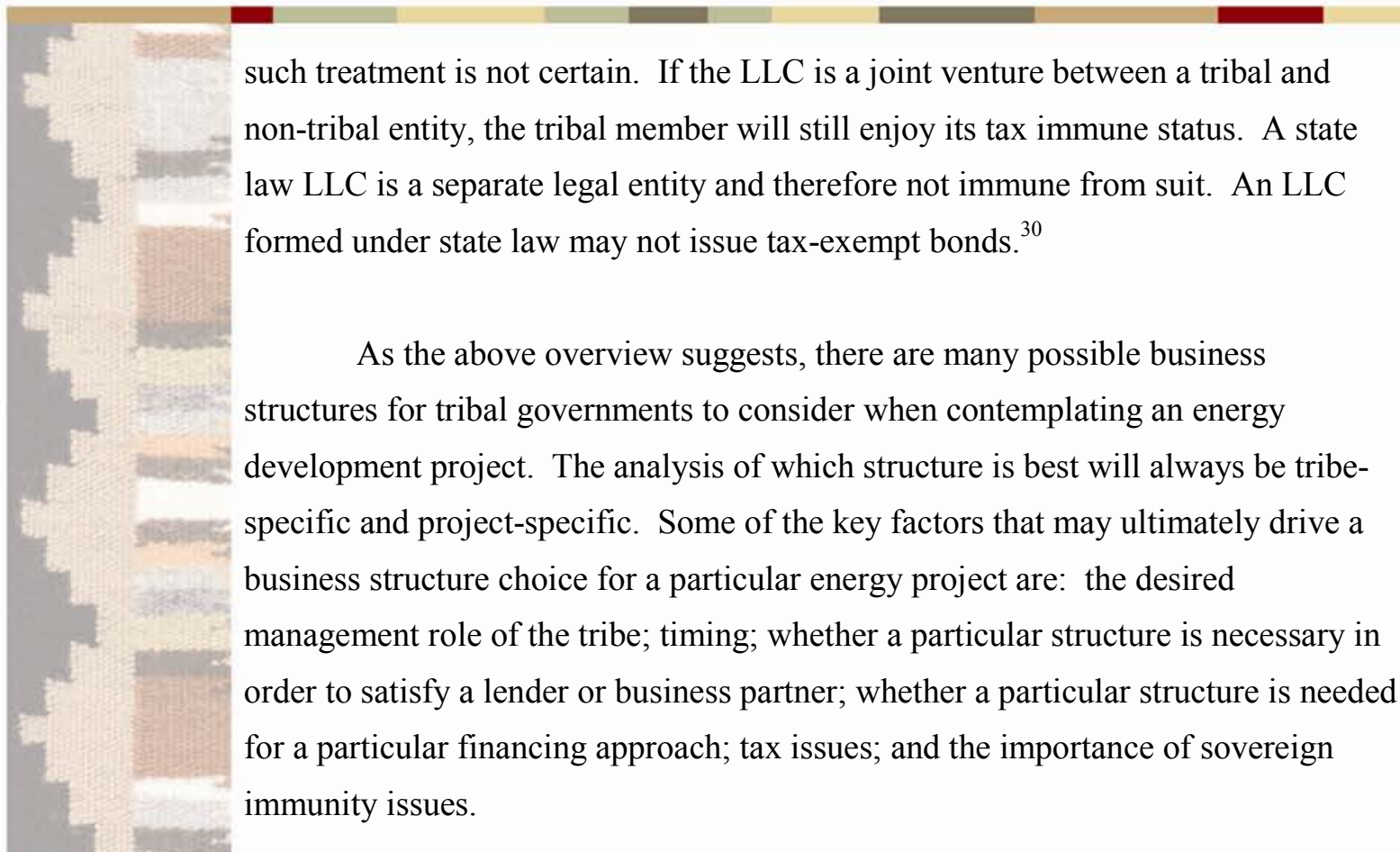

In many cases, a tribe may decide to develop an energy project jointly with a business partner. Because this approach is increasingly common and brings with it a unique set of issues, it is discussed in the following chapter.

${ }^{30} I d$. 


\section{WHAT IS JOINT DEVELOPMENT?}

Joint development is when a tribal sponsor and a developer or investor form a project entity to carry out development together. ${ }^{31}$ This type of project entity is often referred to as a "joint venture."32

\section{Why PARTNER WITH NON-TRIBAL BUSINESS ENTITIES?}

There are a number of reasons why a tribe might decide to partner with a non-tribal business entity for development of an energy project. In the energy context, tribes are motivated to partner for three primary reasons: (1) to acquire energy project development expertise that the tribal project would otherwise lack; (2) to secure project financing; and (3) to get the benefit of federal incentives (e.g., tax credits).

\section{What Types of Entities are Potential Project Partners or INVESTORS?}

There are a number of types or combinations of partners/investors that may be interested in developing a project with a tribe. In order for tribal managers to confidently navigate the renewable energy development market it is critical that they become familiar with some of the "players" they might encounter along the way.

Strategic investors are often companies with some experience in the energy sector that wish to compliment their own growth by investing in a tribal project. A strategic partner will have a capacity to
What is an Equity Investor? An equity investor invests money in a company in exchange for "equity" or ownership in the company. An equity investor's ownership in a private company often takes the form of "shares" and is often referred to in terms of the percentage of total shares (e.g., a 25\% minority shareholder).

\footnotetext{
${ }^{31}$ Parties may also enter into joint venture agreements for construction and/or operation of an energy project, but this Handbook focuses on agreements for joint pre-construction development.

32 The author appreciates the assistance of Ms. Nancy Wodka, Managing Partner of Bracewell Giuliani LLP's Washington D.C. office, in reviewing this chapter and helping to develop some of the concepts presented through her work with the author on tribal energy projects and in presentations with the author in national tribal energy conferences.
} 
assume a fairly high level of risk in development of the project and in return will likely want an active role in management of the project. A strategic investor will likely obtain an ownership interest in the project or project company, and may seek other valuable attributes of the project such as a license arrangement, a power marketing or distribution arrangement, some sort of collaborative development agreement with your company, or an option to own the tribal project.

Institutional investors, which may include financial institutions, insurance companies, or investment funds, are often interested in becoming equity investors in renewable energy projects in order to take advantage of tax credits and depreciation benefits, and to achieve a market rate of return on project financing. These investors are mainly passive, will not accept significant development risk, and are usually not interested in long-term ownership of a project.

\section{HOW DOES JOINT DEVELOPMENT WORK?}

Once a tribe has identified a potential partner/investor for an energy project, the parties will need to create a safe process for negotiations. The first step in negotiations is often a non-binding letter of intent coupled with a confidentiality and nondisclosure agreement. Together, these agreements set the basic tone for discussions between the tribal sponsor and the developer or potential partner and allow both parties to share information without fear of disclosure to competitors. At this early stage most non-tribal parties will accept dispute resolution pursuant to tribal law. This creates an opportunity for the tribe to demonstrate its capacity to support the project.

One of the first topics to be discussed is what type of entity the parties should form to undertake joint development of the project. The tribal sponsor must also consider what type of tribal entity will be the party to the joint development agreement.

As discussions between the parties proceed, the next key step is drafting a joint development agreement that clarifies and memorializes the intent of the 
parties. The agreement should be comprehensive in scope, detailing virtually all aspects of the joint development.

The following sections explore these issues in greater detail.

\section{ChOOSING AN ENTITY FOR JOINT DEVELOPMENT}

As noted above, one of the first topics that the parties should discuss is what type of entity the parties should form to undertake joint development of the project. Three of the most common types of entities that can be used for creating a joint venture between a tribe and a non-tribal business partner include: a corporation, a limited liability company, or a partnership. Regardless of which of these entities are used, both the tribe and the other party likely will have an equity interest in the joint venture entity. Thus, determining which type of entity to use will depend on which set of advantages and disadvantages best fit the particular project.

\section{CORPORATION AS A JOINT VENTURE ENTITY}

The most desirable feature of corporate status is that corporate owners enjoy complete protection from personal liability for the activities of the corporation. However, the tax consequences of forming a corporate joint venture may make it the least attractive of the three options for a tribe. This is because unless a corporation is a wholly owned Section 17 corporation or a wholly owned tribal corporation, ${ }^{33}$ it is subject to federal income tax. A non-tribal owner of a corporation may also be required to pay income taxes on any income it receives from the corporation in the form of dividends or distributions. Therefore, unless certain circumstances require the parties of the joint venture to operate as a corporation, the parties will generally be better served by forming either an LLC or a partnership. It should be noted, however, that even an LLC or partnership presents some tax issues when a tribe or other tax-exempt party

\footnotetext{
${ }^{33}$ The federal tax treatment of tribal corporations, even when wholly owned by a tribe, is uncertain. Most tribes currently take the position that a wholly owned tribal corporation is not subject to federal income taxation.
} 
participates in the ownership. ${ }^{34}$ A corporate joint venture can be formed under either state or tribal law and will be governed by a corporate charter.

\section{PARTNERSHIP AS A JOINT VENTURE ENTITY}

There are two types of partnerships that a tribe and non-tribal entity might consider for formation of a joint venture entity. The main difference is the extent of personal liability that each partner assumes for the activities of the partnership. In a general partnership, both the tribe and non-tribal entity assume full liability for the activities of the joint venture partnership. In a limited partnership there are both "general partners" and "limited partners." At least one "general partner" must assume full liability for the activities of the joint venture, while the "limited partners" enjoy limited liability (limited to the amount of their contributions to or equity in the partnership). Limited partners cannot be involved in management of the partnership.

Both types of partnerships enjoy the same tax status. Partnerships are not directly subject to federal income tax. Instead, each partner reports its share of the partnership's income (or losses) as part of its own annual income. In other words, the income and tax consequences from a partnership "flow through" the partnership to the individual partners. Because the partnership itself does not pay tax, partnerships are referred to as "flow-through" or "pass-through" entities. This type of entity is especially attractive to tribes because the IRS has stated that a tribal partner in a partnership is not subject to federal income tax. ${ }^{35}$

\section{LLC AS A JOINT VENTURE ENTITY}

The LLC is probably the most common entity choice for joint ventures between tribes and non-tribal businesses because it is a hybrid that combines the limited personal liability of corporate status with the "pass-through" tax

Some tribes, such as the Navajo Nation, have adopted LLC codes to promote tribal business ventures.

${ }^{34}$ These tax issues are discussed in detail in Chapter Seven.

${ }^{35}$ See Internal Revenue Manual 4.88.1.4.1 (Federal Tax Status of Indian Tribal Governments) (January 1, 2003). 
feature of partnerships. If a tribe and non-tribal entity want to enter into joint development of an energy project that permits the non-tribal entity to play an active management role, but allows the tribe to retain the advantages of its taxexempt status, then the LLC will likely be the best entity for the project. The disadvantages to conducting joint development through an LLC include that an LLC is not likely to have sovereign immunity and may have some limits on financing options (e.g., an LLC is not able to issue tax-exempt bonds). In addition, tribal participation in the equity ownership of an LLC can create significant challenges for obtaining the benefit of federal tax credits and accelerated depreciation. These challenges are discussed in Chapter Seven.

\section{WHAT TYPE OF TRIBAL ENTERPRISE SHOULD BE THE PARTNER/MEMBER IN A JOINT VENTURE?}

Once a tribe has decided to enter a joint venture with a non-tribal business partner and has settled on the type of joint venture entity that will be used, the tribe should consider its own business structure. It may want to directly participate as a tribe or utilize one of the tribal business enterprises discussed above (e.g., Section 17 Corporation, a single-member LLC, or a political subdivision). The tribe's potential business partner may have some requirements in this regard, such as requiring a particular type of entity and/or a waiver of sovereign immunity. The tribal business entity must have clear and transparent support and independent authority from the tribe or the Native Corporation to conduct necessary development tasks.

\section{What is a Joint DeVelopment AgReEment?}

A joint development agreement is a detailed agreement between the joint venture partners that establishes the basic framework of the relationship by detailing the pre-construction project development process and allocating rights, duties and obligations between the two entities. The joint development agreement also sets the tone and "template" for all future agreements between the tribal sponsor and the non-tribal business partner. The following outline lists some of the key terms and considerations for a joint development agreement for an energy project between a tribe or tribal enterprise and a non-tribal entity: 


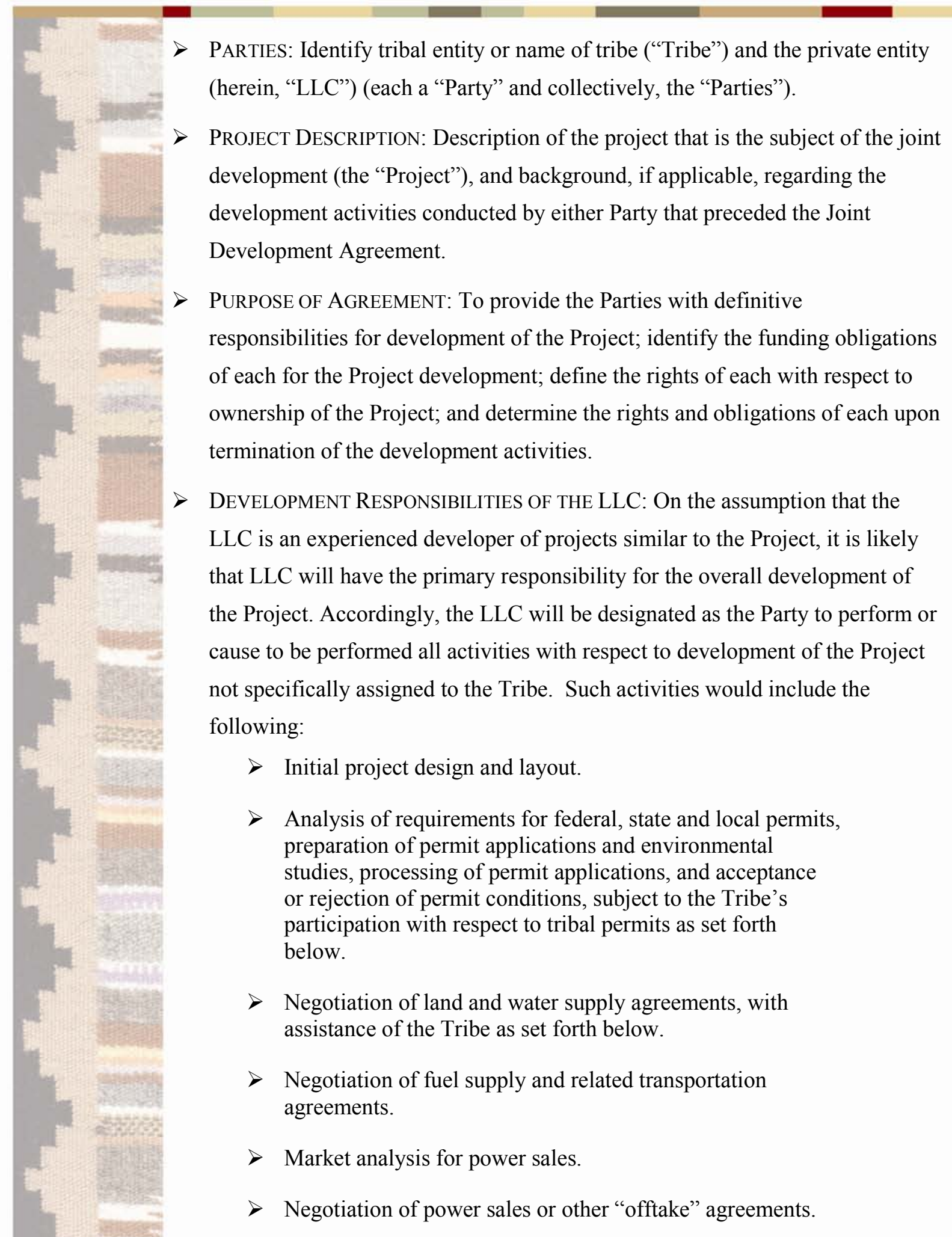


Negotiation of interconnection and transmission agreements.

$>$ Selection and management of external advisors, including but not limited to environmental consultants, financial advisors, tax advisors and legal advisors representing the Project and negotiation of contracts with such persons.

$>$ Selection and management of engineering and construction contractors, and negotiation of contracts with such persons.

$>$ Community outreach and government relations programs for the Project.

$>$ Preparation, management and modification of Project financial projections.

Structuring of the Project's debt arrangements, selection of lenders, and negotiation of agreements for the Project's financing.

$>$ Selection of additional equity investors (in addition to the Tribe) in the Project and negotiation of agreements with same.

Developing operation and maintenance plans and budgets.

DEVELOPMENT RESPONSIBILITIES OF THE TRIBE: The development activities of the Tribe are usually focused on the relationship with the Tribe and the surrounding community. If there are resource agreements to be entered into with the Tribe, such as lease or easement agreements for the land, water or fuel supply agreements, tax arrangements, and/or agreements to give priority to tribal members or businesses for the labor or other business needs of the Project, it is likely that the Tribe would be instrumental in making such arrangements. Accordingly, the Tribe's development activities generally include the following:

Assisting with negotiation of lease or other land use arrangements with the Tribe (subject to Federal regulations).

Assisting with negotiation of water and fuel supply arrangements to the extent such resources are controlled by the Tribe. 


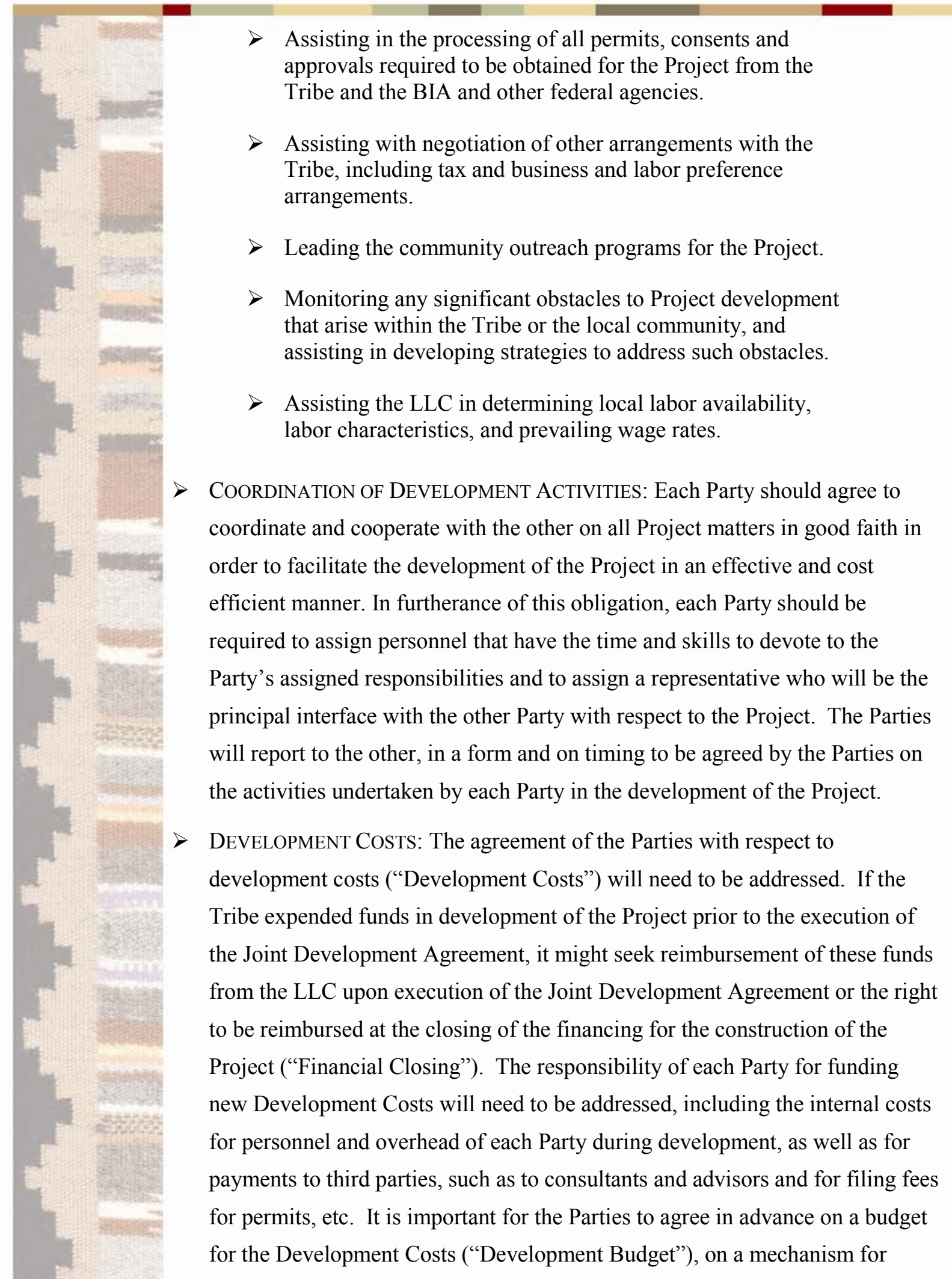


revisions to the Development Budget and for milestones or other circumstances that must be met for continued funding, in order to avoid surprises and disagreements between the Parties. The Parties also may agree upon fees to be earned by a Party during Project development to defray its internal costs, and/or success fees to which one or the other or both will be entitled at Financial Closing in order to reward a Party for the financial risk that it has undertaken during the development of the Project.

$>$ Ownership of Project Assets And Work Product: Ownership of data, information, studies, analyses and reports developed by either Party in the performance of the Project development ("Work Product") and of any Project permits obtained during development will need to be addressed. If the Work Product and permits are obtained by one Party, it should be stated that such Work Product or permit will be the property of the Project Company upon its formation or at a specified time and, until then, will be held by an individual Party in trust for the Project Company. The Parties should agree to share Work Product but should also determine whether there is Work Product for which disclosure to third parties (other than Project consultants) should be restricted. If the Tribe has the equivalent of a "freedom of information act" or other regulations that would treat any information held by a tribal entity as public information, the Parties will need to determine mechanisms under which they will seek protection for the confidentiality of non-public or proprietary information.

$>$ AfFILIATE CONTRACTS: The arrangements for contracts between either of the Parties or their affiliates, on the one hand, and the Project Company, on the other hand, should be described, e.g., by including a requirement that the terms and conditions be negotiated on an arms-length basis and be reflective of market conditions and/or by having the affiliated Party step out of the negotiations.

TERM Of AGREEMENT: The Joint Development Agreement should include a stated term so that termination can occur either automatically or upon notice issued by a Party if successful development does not occur within a stated 
period of time. If successful development does occur, the Joint Development Agreement would be superseded by a joint ownership agreement.

TERMINATION RIGHTS: In addition to a stated term, the Joint Development Agreement should include a specific list of events or circumstances that would allow a Party to terminate the agreement prior to the end of the term. These may include such events or circumstances as the following:

$>$ Failure of key milestones to have been met by agreed dates;

$>$ Discovery of an impediment to development of the Project that a Party demonstrates, after attempting to cure the problem, is irresolvable;

$>$ A Party's determination that even if the Project is successful, it does not want to proceed with the Project (note: this may come with penalties for withdrawal from the project);

$>$ A Party's failure to perform its material obligations under the agreement (subject to notice and cure periods); or

$>$ The bankruptcy or insolvency of a Party.

The Joint Development Agreement should address the consequences of any such event or circumstance, including notices that must be given before a Party can exercise a right of termination and the effect of termination on the Parties' rights. In the circumstances described in the first two events or circumstances listed above, the Parties may wish to provide for a period of consultation before a Party can terminate to determine if it there are means by which the milestone can be achieved within a reasonable period of time or if there is a way to resolve or avoid the impediment. If there is a consultation period, the length of the period should be stated to limit the chance for a dispute over whether a Party has properly exercised its right of termination. The rights of the Parties upon termination must be clearly addressed. This includes whether one or the other Party has the right to continue development in the absence of the other Party; ownership of Work Product; obligations to assign Project permits and/or contracts to the continuing Party, if any; and obligations of a continuing Party to reimburse the other Party for its 
unreimbursed Development Costs upon further sale or successful development of the Project.

EQUiTY PARTICIPATION IN PROJECT: Although the Joint Development Agreement is intended to cover the period prior to the determination to proceed with construction of the Project and the formation of a formal joint ownership arrangement between the Parties, it would be advisable for the Joint Development Agreement to address the rights that each will have with respect to ownership of the Project. It is likely that an entity (the "Project Company") will be formed for the joint ownership of the Project either during development or in any event prior to Financial Closing. The form of joint ownership will depend on a number of factors, including tribal laws and customs, tax considerations, and whether or not there are expected to be additional equity participants in the Project. It is not uncommon to use a limited liability company for such arrangements, formed either under Delaware law or under the law of the state where the Project is to be located. In circumstances where the Parties are mutually funding the Development Costs and contributing to the development activities, it is likely that the Parties will have equal rights to ownership of the Project Company. On the other hand, if development of the Project is being primarily funded by the non-tribal entity, the rights of the Tribe to obtain an equity interest in the Project should be stated, based on the reasonable expectation of the size of the equity share in which the Tribe is interested and that it will have the capability to fund. Since it is unlikely that lender financing for $100 \%$ of the Project construction costs will be available (a debt/equity structure of 70/30 or 80/20 is more likely for a Project financing), the Tribe will need to be able to fund its contribution toward the equity required for Project construction. Contributions in kind, such as rights to land, water or other tribal resources might substitute for monetary equity contributions, at least in part. In any event, since the right of the Tribe to obtain an equity interest in the Project or, conversely, the right of the non-tribal entity to sell a portion of the equity interests to a third party are key Project considerations, these rights should be plainly set forth in the Joint Development 
Agreement, including the timing and circumstances for the exercise of such rights.

\section{RIGHTS OF EQUITY PARTICIPANTS IN THE PROJECT COMPANY: The Joint}

Development Agreement also may include an outline of the key provisions that will be set forth in the joint ownership agreement such as the "limited liability company operating agreement." For example, it may specify that a management committee or board of directors will be formed, and provide for the voting representation that each Party will have on such governing body, either pursuant to each Party's equity share or on some other basis negotiated by the Parties. Issues to be considered for joint ownership agreement include:

$>$ the capital structure of the Project Company;

$>$ the obligations of each participant for initial equity contributions for the Project;

additional funding obligations, if any, as capital needs of the Project arise from time to time;

$>$ rights of other parties upon a party's failure to fund required equity contributions;

$>$ the mechanics of Project Company decision making, including matters that will be delegated to the professional staff and those that will require a simple majority vote, supermajority vote and/or unanimous agreement of the equity participants;

allocations of profits and losses;

agreements with respect to tax matters and tax elections (particularly important if the parties choose for the Project Company to be taxed as a partnership);

$>$ the timing of cash distributions to the equity participants;

$>$ limitations on and/or consent rights or rights of first refusal with respect to the transfer of equity interests;

events that will constitute the default of an equity owner and the remedies for such default;

$>$ dissolution of the Project Company and end of term considerations; and 
dispute resolution, and if necessary, a mechanism for resolving deadlocks on major decisions.

ASSIGNMENT RIGHTS: The rights of a Party to assign its rights or obligations under the Joint Development Agreement should be covered and any exclusions to the requirement to obtain written consent to transfer (e.g., to an affiliate) should be stated.

NATURE OF RELATIONShiP: The Joint Development Agreement should state that it does not create a partnership or joint venture or similar arrangement between the Parties, that neither Party will be deemed to be an agent or representative of the other Party, and that neither Party shall have the authority to assume or create any obligation of the other Party or to bind the other Party without that Party's consent.

$>$ Complance With LaW: The Parties should agree to adhere to all laws, including tribal laws, applicable to the Parties or the Project during the development of the Project.

$>$ GOVERNING LAW: Governing law is likely to be a controversial issue for the Parties to resolve. The Tribe will likely desire that the Joint Development Agreement be governed by its tribal laws, while a private entity such as LLC will prefer the laws of a jurisdiction with which it has familiarity and for which there can be predictability through the LLC's understanding of the jurisdiction's laws and precedents. If the laws of the Tribe are highly developed and the determinations of its courts are readily accessible by nontribal members, the Tribe will have greater success at arguing for the tribal laws to govern the contract. However, it would not be surprising for LLC to desire that the agreement be governed by the laws of a state with a well developed body of commercial law, such as the laws of the State of New York, which is often specified for complex and costly commercial ventures. (See Section 5-1401 of the New York General Obligations Law which provides for such choice of law.) Bear in mind that although the Joint Development Agreement may set a precedent for the Parties' negotiation of other arrangements, it is feasible for the Joint Development Agreement and joint 
ownership agreement to have a different governing law than the arrangements that involve the use of tribal resources such as land, fuel or water.

DISPUTE RESOLUTION: A mechanism for resolving disputes and claims under the Joint Development Agreement should be specified. While the efficacy of arbitration is a heavily debated topic, it might be a useful middle ground for the Parties as opposed to trying to reach agreement on whether the tribal courts or state or federal courts will be used for dispute resolution.

WAIVER OF SOVEREIGN IMMUNITY: The LLC is likely to request that the Tribe waive its sovereign immunity in light of the commercial nature of the Joint Development Agreement and related joint ownership agreement, at least insofar as such waiver is necessary to preserve a Party's rights to pursue the agreed-upon dispute resolution mechanism. Many tribes grant limited waivers that protect certain tribal assets and impose other conditions on the scope of the waiver in order to secure contracts. Legal counsel should be consulted on the precise text, and tribal law may require specific procedures or approval by tribal council for the waiver or limited waiver to be valid.

\section{General Provisions InCL Uded in DeVelopment and Other Energy} PROJECT AgREEMENTS SUCH AS THE PSA AND TRANSMISSION AgREEMENTS

In addition to the key provisions described above, each of the contracts in an energy project including the PSA, transmission services agreement, and interconnection agreement will likely include the following concepts and provisions:

INDEMNIFICATION. In an indemnification provision, one party agrees to defend and hold harmless another party under circumstances where the indemnifying party either was negligent or deliberately failed to do something it was obligated to do or perform. The indemnity provision may require a party to pay the other parties' damages and attorney fees. The issues of what a party is responsible for are pretty clear when damages are directly related to a party's actions. The identification of responsibility is much harder when damages indirectly arise from a party's actions, or non-actions. The parties often will 
agree to waive claims for consequential damages such as lost profits or other indirect damages

FORCE MAJEURE EVENTS. The force majeure provision covers what responsibilities the parties have when the project experiences problems because of acts of nature (flood, earthquakes, hurricanes) and some other events that the parties cannot control or reasonably foresee. Usually if a party cannot perform its responsibilities as a result of one of these events, it is not in default so long as it diligently works to mitigate the effects of the event. It is important to read any proposed force majeure clause carefully to make sure it does not include controllable or foreseeable events such as the failure to secure appropriate transportation or make other important arrangements or the mere fact that a price has increased or that an act has become more difficult. The basic premise of this clause is to protect a party when a party's performance is impossible not just more difficult, as a result of the event, and the event was not something that could be controlled or be reasonably foreseen.

FURTHER ASSURANCES. The provision governing further assurances involves the giving of security in some form (e.g., cash deposit, letter of credit, ability to operate, etc.) when a party is concerned about the ability of the other party to perform its contractual obligations. This provision may be extensive in the case where one party has poor credit or has limited resources to apply to its obligations under the contract. Frequently the agreement will contain a requirement to post a financial guarantee of a party's performance of its obligations.

INSURANCE REQUIREMENTS. Project developers will be required to carry certain levels of insurance coverage as part of the agreement. This provision will identify the types and amounts of insurance the project needs to obtain.

PARTY “CORPORATE” APPROVALS. Usually each party to the agreement wants the assurance of a board resolution, or some similar governing-body approval, giving the other parties' representatives the authority to negotiate and execute the necessary agreements and endorsing the main elements of the transaction. 


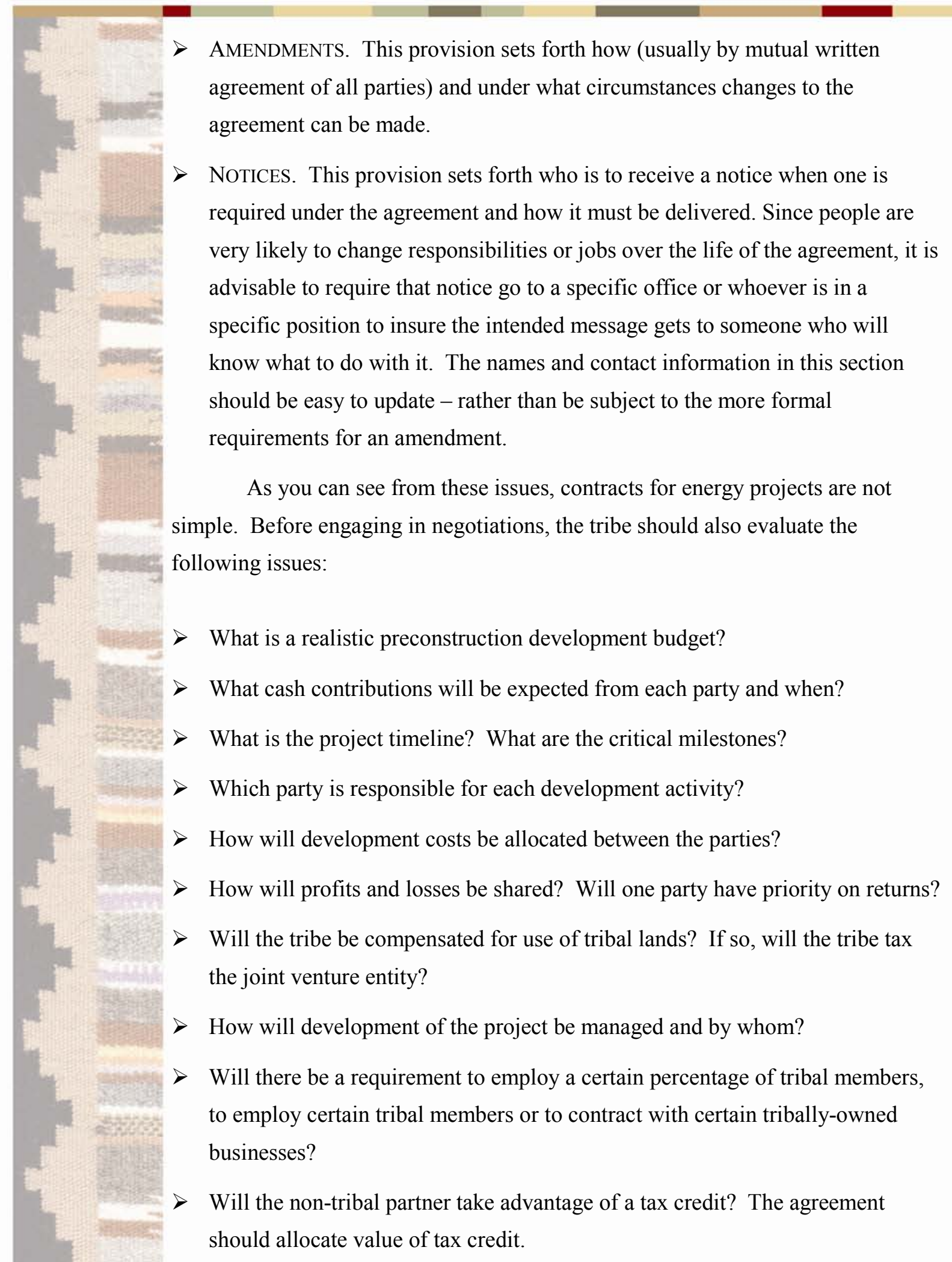


If the tribe will be a minority shareholder in the joint venture, it should consider negotiating terms to protect its minority interest in the project, including, for example:

- Rights to approve certain material matters, such as a sale of the project, admission of an additional joint venture partner, or dissolution of the joint venture;

- Rights to participate in issuances of additional equity interests in the joint venture;

- Caps on required capital contributions to the joint venture;

- Rights to participate in material decisions regarding the project;

- Rights for use of tribal members in project workforce; and

- Rights to approve public statements regarding the project.

How will the parties resolve any disputes that arise from the joint development agreement? In particular, the parties need to reach agreement on:

- The nature and extent of the tribal partner's waiver of sovereign immunity, which is often essential. The tribe may be able to limit its waiver to specific assets and include protections for tribal officials;

- Arbitration v. litigation of disputes. Ideally, the agreement will require binding arbitration and give a competent court (one with clear jurisdiction over the dispute) authority to compel arbitration and enforce binding awards; and

- Tribal court v. state court. The tribe should try to include clear terms preserving tribal jurisdiction, such as a covenant not to contest tribal jurisdiction and requiring exhaustion of remedies in tribal court before going to a state or federal court.

How will the parties handle dissolution of the joint venture if it becomes necessary? 


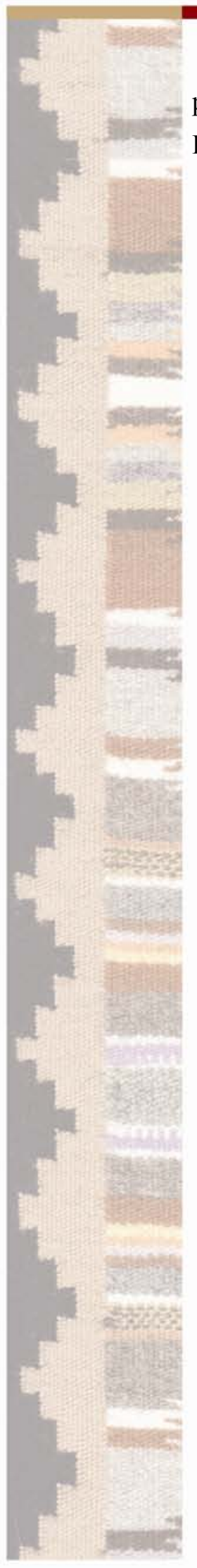

The above list is not intended to be exclusive; every renewable energy project will have a unique set of issues and terms that drive the terms of the Joint Development Agreement or other tribal energy project agreements. 
Any party involved in the development of a renewable energy project will at some point find itself entering into a variety of legal agreements, ranging from relatively simple agreements for the purchase of technical services to complex long-term financing or ownership agreements.

It is beyond the scope of this Handbook to provide detailed information about every contract that might be required in the course of developing a renewable energy project. The following section provides an overview of three types of agreements that are central and universal to almost every energy project, as well as insights and tips for tribal managers involved in contract negotiations. The previous chapter discusses provisions common to these agreements as well.

\section{Power Sales Agreements}

WHAT IS A PSA?

Once an energy developer has identified one or more potential customers and is ready to secure a long-term commitment from a power purchaser, it will begin to negotiate a power sales agreement or PSA. As the name implies, a PSA sets the terms and conditions for the sale of power from the project. ${ }^{36}$ A wellcrafted PSA is a pivotal element of a successful energy project. With some exceptions, the basic terms and conditions are the same no matter whether the PSA deals with the output of a thermal, hydro or wind power project.

In order to understand and negotiate a PSA, it is necessary to understand certain basics about how electrical energy is purchased and sold. Electrical power is sold by two components: capacity and energy. Capacity is expressed in MW (megawatts). Capacity is of two types. The manufacturer's rating of the generating equipment's capability is the "nameplate capacity" of the equipment. In a project with more than one generator, such as a wind project, the project's nameplate capacity is the sum of all the units in the project. The other type of capacity is the MWs the project is most likely to make available in day-to-day operation. It is the net amount of the nameplate capacity reduced by the project's

\footnotetext{
${ }^{36}$ Power purchasers sometimes refer to this agreement as a Power Purchase Agreement or PPA, but the PSA and PPA are one and the same.
} 
capacity factor and availability factor (see the glossary at the back of this Handbook). This latter is the capacity level that will be used for the energy production commitments that will be made in the PSA. The capacity price generally is designed to recover the fixed and capital costs of the project over a 20 to 30 year period much like a mortgage payment. Energy is the power, measured in MWh (megawatt hours) or kWh (kilowatt hours), actually delivered from the project. Another way to look at the price of the energy component is that it is set to recover the variable costs of producing the power delivered during a month.

The project's customers may have the choice of purchasing firm or interruptible energy and capacity. Firm energy is priced higher and is often associated with rights to project capacity. Interruptible energy can be relatively inexpensive and usually is not associated with any rights to capacity. Customers with firm capacity rights have the first call on project output. Firm capacity and energy is often subject to a "take or pay" provision in the pricing section of the PSA, which requires the customer to pay whether or not they actually take any power. Obviously the project has to be up and running and making power available according to the requirements of the PSA in order for the take or pay provision to be enforceable.

\section{KEY PROVISIONS OF A PSA}

The following are most of the key provisions in a PSA:

BUYER PROMISES TO PURCHASE. The core of the PSA is the purchaser's commitment to purchase power produced at a certain price.

DEVELOPER PROMISES TO DELIVER POWER. The project or seller's core commitment is to deliver a certain amount of power (MWh delivery expectations) to specified delivery points - these generally will be the connection points with the transmission provider or at a meter or transformer in the project substation or switchyard. 
THE "COMMERCIAL OPERATION DATE" (COD). This is the date on which the project will be put into regular service and fully subject to all of its delivery obligations in the PSA.

TERMS OF PAYMENT. The parties must agree how and when the purchaser will make payments and whether "green attributes" are included in the purchase price or priced and sold separately. Parties to a PSA will often include a mechanism for changing the price over the term of the agreement. This may be indexed to an agreed inflation measure, such as one published by the U.S Department of Commerce, or the cost of key inputs such as fuel or a set amount at agreed intervals over the life of the PSA.

TERm Of AgreEment. The parties must agree to a specific term for the initial length of the agreement (usually at least 20 years, but at least as long as the project financing loans). The PSA should also provide for a certain number of renewals for shorter periods (usually no more than 5 years).

$>$ CONDITIONS PRECEDENT TO THE PARTIES' RESPONSIBILITIES. In many cases project developers will secure a PSA for the power output from a project long before the project is completed. It is not unusual for parties to enter into a PSA before project construction has commenced because a project developer may need to have a signed PSA before it can secure financing. Many lenders and investors want to see proof that a project will have a fixed revenue stream upon completion before investing in it. Because of this "cart before the horse" situation, both parties need detailed provisions that protect them in the event that the project fails, falls behind its construction schedule or does not perform according to expectations. These provisions set "conditions precedent to the parties' responsibilities." In other words, the buyer will only be required to satisfy its obligation to buy power if the developer successfully performs its required tasks to produce and deliver it. Those tasks also include deadlines that must be met to trigger an obligation or right under the PSA. Among them are: closing project financing; applying for and obtaining necessary permits and approvals; meeting construction milestones; successful equipment testing; and commissioning and completion of ancillary agreements. 
CONSTRUCTION AND PROJECT IN-SERVICE DEADLINES. If the project gets significantly behind schedule, it can have serious consequences beyond any inconvenience that results. In the case of a wind project, the right to receive production tax credits (PTC) will usually depend on the project's being in commercial service by a date set in the federal legislation authorizing the PTCs.

$>$ GOVERNMENT APPROVALS REQUIRED AND WHICH PARTY IS RESPONSIBLE FOR SECURING THEM (SUCH AS LAND USE, CONSTRUCTION, ENVIRONMENTAL).

Government approvals are usually the responsibility of the project developer, with project owners and operators having responsibility for continuing compliance and reporting once the project achieves its COD.

UTILITY REGULATORY APPROVALS AND FILINGS. These may be required for the life of the project and may include state and federal regulatory proceedings. Frequently the project will be regulated at the state level, but could be subject to both federal and state regulation. Interstate transmission service is regulated at the federal level. State and federal jurisdiction will vary with land ownership and tribal jurisdiction.

SUPPORTING AGREEMENTS REQUIRED. The PSA may require successful completion of other key agreements, such as transmission and interconnection agreements or plant operation and maintenance agreements.

RESPONSIBILITY FOR RESERVE POWER AND "SHAPING". The PSA should set which party arranges and pays for reserves or backup capacity for unexpected loss of power production from the project or reduced transmission transfer capability. A certain level of reserves is required in order for the product to be interconnected with the transmission grid. "Shaping" adjusts project output over a given time period - for instance, to ensure that the output level is steady even if the wind is variable or stops, which usually requires a separate agreement with another generation project that operates in a base load manner on fossil fuel or possibly a hydroelectric project.

PROJECT EQUIPMENT. A PSA usually includes several provisions relating to the project equipment and how its maintenance or failure might affect the 
project's ability to meet power delivery expectations. These provisions outline any indemnity or compensation available to the power customer.

DEFAUlTS AND REMEDIES. This sets the hierarchy of things that could go wrong and what events are serious enough to give one of the parties the right to terminate the agreement or be entitled to damages. There will be considerable negotiation on these terms.

\section{TRANSMISSION \& INTERCONNECTION AgREEMENTS}

\section{WHAT ARE TRANSMISSION AND INTERCONNECTION AGREEMENTS?}

Transmission is key to development of a successful energy project. All energy projects will require transmission of the project's power output to the power purchaser(s). From a practical standpoint, agreements for transmission service are the culmination of significant efforts and analysis by the receiving customer or the project developer to identify a cost-effective interconnection to an existing transmission system. Agreements for interconnection often include construction requirements and, like in the PSA, both parties might require certain protections in order to limit their exposure to risks. For example, the project developer generally needs a contractual commitment from the transmission provider before it begins construction of the necessary interconnection equipment. The terms and conditions for transmission service will often consist of two separate agreements:

$>$ INTERCONNECTION: Project and transmission provider enter into an agreement for connection of the project to the provider's system.

TRANSMISSION: Project or power purchaser and transmission provider enter into an agreement for the transport of power to the purchaser's delivery point.

There is likely to be much less negotiation over the terms and conditions of the transmission agreement than with the PSA since the service will almost certainly be provided pursuant to state or federal tariffs or regulations that require 
all customers be served on roughly equal terms. The rates probably will be determined by the transmission provider's tariff, which may provide for "market based" negotiated rates. U.S. Federal Energy Regulatory Commission's (FERC) regulations require that all parties are treated in a similar fashion and have open access to the transmission system. Reservations of capacity and information about the transmission system are made on the provider's OASIS (Open Access Same Time Information System) web site. The primary issues will be whether there is enough available capacity to provide service, which party will fund and construct the interconnection facilities, and what level of credit support will be required from the party receiving the transmission service. There may be a queue for service since transmission capacity is only added in block increments. The provider may require that a system study be performed, at the project's expense, to determine if capacity is available and the conditions under which the project may be connected to the system.

The transmission agreements must be pursued early in the development process to allow time for studies to be performed, equipment specified, and capacity verified. It is important to note that a project might not be able to obtain transmission service within its preferred time constraints and that the project might have to construct a connecting transmission line at its own expense in order to obtain transmission service even if service is available at the connection point to the grid.

Many of the terms of a transmission services agreement will be subject to regulatory requirements or the provider's tariff. Some of these terms may go in the transmission services agreement and the interconnection provisions could be merged with it or be an exhibit to it. For purposes of this discussion, we assume that the transmission services agreement and the transmission interconnection agreement are merged into one. The purpose of an interconnection agreement is to establish the requirements, terms and conditions for the interconnection of the generator's facility with the transmission system of the transmission provider. 
KEY PROVISIONS OF TRANSMISSION SERVICES/INTER CONNECTION AGREEMENTS

TRANSMISSION SERVICE. Transmission provider promises to provide transmission service over its transmission system.

Purchase Obligation. Project developer /generator promises to purchase transmission services from provider.

$>$ SERVICE RATES. Rates for transmission service are generally set by provider's tariff.

$>$ TERM OF AgREEMENT. The parties must agree to a specific term for the initial length of the agreement and renewal terms. The term usually corresponds to the term of the PSA, though the rates will vary over time.

$>$ COnditions Precedent to the Parties' Responsibilities. Completion of interconnection facilities is often a condition precedent to the transmission services agreement. In an interconnection/transmission agreement, the transmission provider often commits to the engineering study and design work necessary for interconnection. The project developer often agrees to pay for design and construction of all equipment and facilities and may, in some cases, be responsible for construction. Interconnection and transmission may also be contingent on the project's closing of certain financing or funding.

$>$ CONSTRUCTION AND PROJECT IN-SERVICE DEADlINES. The agreement should specify construction deadlines and in-service deadlines.

$>$ OWNERSHIP OF INTERCONNECTION FACILITIES. Even if the project funds the construction of the facilities, the provider may require title to the facilities. Depending upon circumstances, the project may be indifferent to whether it has title or not, especially if some liability or maintenance obligation comes with ownership.

GOVERNMENT APPROVALS. The agreement should note which government approvals are required (such as land use, construction, environmental) and which party is responsible for securing them. Government approvals are usually the responsibility of the project developer, with project owners and 
operators having responsibility for continuing compliance and reporting once the project achieves its COD.

UTILITY REGULATORY APPROVALS AND FILINGS. These may be required for the life of the project and may include state and federal regulatory proceedings. Usually the project will be regulated at the state level and the transmission provider at the federal level.

SUPPORTING AGREEMENTS REQUIRED. A transmission services agreement will often make references to other related agreements, such as a power sale agreement or a funding agreement.

PROJECT EQUIPMENT: The transmission provider usually specifies all interconnection equipment.

\section{Agreements ReLating to DeVelopment of An ENERGY PROJECT ON TRIBAL LANDS}

Energy project development is inextricably intertwined with land. The cost-effectiveness of an energy project depends on the land available for a particular generating resource as well as the land available for transmission. For that reason, a tribe's assessment of its energy resources must include a review of land ownership of particular parcels to determine what types of leases, easements, rights-of-way or licenses may be necessary for development of a particular project.

Tribes own and control land in a variety of forms. Except for Alaska Natives, the most common form is trust title, where fee title is vested in the United States on behalf of and for the benefit of the tribe. Tribes may also own land in fee title, restricted fee title and other forms. Trust lands, hereinafter referred to as "tribal lands," are the most common. As explained below, tribal authority to "alienate" tribal land is restricted by federal law. Because the applicable law for "leasing" differs from that governing "rights-of-way," each topic is addressed separately. 
Surface leases (as opposed to mineral leases) are popular vehicles for establishing the necessary land rights for energy projects, largely because of the long term that can be authorized ( 25 to 99 years), and because security interests may be taken in the leasehold and in other assets that do not include the Indian land such as the wind towers or PV arrays. Tribes may use their lands for any purpose consistent with tribal and federal law, including granting tribal members rights to occupy and use tribal land. ${ }^{37}$ Yet even when the tribe leases to tribal entities or members, ${ }^{38}$ such a lease requires BIA approval if it "encumbers Indian lands for a period of 7 or more years, with limited exceptions. Section 81 is discussed more fully later in this chapter. Tribes may not sell, transfer or alienate lands held in trust for them by the federal government. ${ }^{39}$ Even tribal authority to lease land to non-tribal members was historically restricted. Federal policy in favor of tribal self-determination, including tribal responsibility for the management of tribal resources," has resulted in the passage of a number of laws granting tribes specific authority to lease tribal lands:

\section{“SECTION 17" CORPORATIONS. The Indian Reorganization Act of 1934} (IRA) specifically addresses leasing authority. Tribes that receive a "charter of incorporation" under 25 U.S.C. $\S 477$ (as amended in 1990) of the IRA may seek authority to lease any trust or restricted lands included in the limits of the reservation for a period not to exceed 25 years without BIA approval. ${ }^{40}$ Leases authorized by Section 477 cannot include an option extending the 25 -year initial term.

$>$ SECTION 415. Most non-agricultural surface leasing of tribal lands is conducted under the Indian Long-Term Leasing Act of 1955, also known as Section 415. ${ }^{41}$ Under Section 415, an Indian tribe may lease tribal land for an initial term of up to 25 years, with an option to renew for one additional 25 year term. Certain specific tribes have legislative authority to lease land for

${ }^{37}$ Cohen, Federal Indian Law at $\$ 16.01[3]$.

${ }^{38} 25$ U.S.C. $\S 81$, as amended in 2000.

3925 U.S.C. $\$ 177$ ("The Nonintercourse Act of 1834”).

${ }^{40}$ See also 25 CFR $\$ 84.004(b)$.

${ }^{41} 25$ U.S.C. $\S 415$; Cohen at $§ 17.02[3]$. 
up to 99 years. Almost all leases pursuant to Section 415 are subject to the approval of the Secretary of the Interior, though two tribes have authority to lease land for up to 75 years without Interior/BIA approval (Tulalip and Navajo).

\section{Tribal Energy Resource Agreements ("TERAs"). Title V of the} Energy Policy Act of 2005 relates to "Indian Tribal Energy Development and Self-Determination." Pursuant to regulations issued on March 10, 2005, tribes can enter into an agreement with the Department of the Interior called a TERA. The TERA authorizes the tribe to enter into leases, business agreements and rights-of-way for energy projects on tribal land for 30 years, renewable for another 30 years by the tribe, all without BIA review and approval.

Despite the TERA option, many leases of tribal land for energy development will likely be subject to BIA approval under Section 415. Because of the unique circumstances of each energy project, tribes should always work with an experienced attorney to understand the leasing issues specific to each parcel. The following is a list of some of the issues that tribal managers should be aware of:

\section{Even a Tribal Entity MaY be SubJect to Limitations as a LeSSEe.}

Any person or legal entity other than the tribe itself, "including an independent legal entity owned and operated by the tribe, must obtain a lease under these regulations before taking possession" of tribal land. 25 C.F.R. $\S 162.104(d)$.

BIA MUST COMPLY WITH NEPA, NHPA AND ESA. BIA must also comply with several key environmental and cultural preservation laws before approving a lease of tribal land, including the National Environmental Policy Act (NEPA), the National Historic Preservation Act (NHPA) and the Endangered Species Act (ESA). BIA compliance with any one of these laws can involve a lengthy process with substantial public involvement and may require mitigation of environmental or other impacts from the proposed project.

\section{In Some Situations, a Tribal Resolution Can Trump Federal}

REGULATIONS. The federal regulations implementing Section 415 can be superseded or modified by tribal laws in certain circumstances. Specifically, BIA will streamline and modify certain approval processes when specifically 
authorized by an appropriate tribal resolution establishing a general policy for the leasing of tribal land. The tribal resolution must comport with 25 C.F.R. $\S$ 162.109(b) (requiring that tribe give BIA notice of the resolution and that the resolution be consistent with federal law).

BIA Must APProve Subleases AND ASSignMENTS. Subject to certain exceptions, a sublease, assignment, amendment or encumbrance of any lease or permit issued under Section 415 requires BIA approval.

\section{SECTION 415 REGULATIONS ADDRESS REMEDIES FOR BREACH, DISPUTE} Resolution, ANd When BIA has the Authority to Cancel Leases.

BIA involvement in a lease of tribal land does not end with BIA approval. Among other things, Section 415 regulations give BIA the authority to collect payments on behalf of the tribe as well as cancel the lease under certain circumstances. See 25 C.F.R. 162.612 et seq.

RIGHTS-OF-W AY AND E ASEMENTS

BIA grants rights-of-way across tribal land subject to tribal consent and compensation. Federal law governs the granting of rights-of-way on tribal lands for transmission lines, hydroelectric facilities and reservoirs. ${ }^{42}$ BIA must comply with NEPA, NHPA, ESA and its own regulations. before granting the right-of-way. Additionally, tribes might need to enter into easements for use of private land in order to secure interconnection and transmission off tribal lands.

\section{BIA APPROVAL OF CONTRACTS WITH TRIBES}

In March 2000, President Clinton signed the Indian Tribal Economic Development and Contract Encouragement Act of $2000^{43}$ into law to encourage outside investment in Indian Country. In the 2000 Act, Congress revised 25 USC $\S$ 81 , more commonly known as "Section 81 " and amended the long-standing rule that required BIA approval for all transactions between non-Indians and Indian tribes or individuals relating to Indian lands.

\footnotetext{
42 U.S.C. $\$ 323-328 ; 25$ CFR Part 169.

${ }^{43}$ Indian Tribal Economic Development and Contract Encouragement Act of 2000 Pub. L. No. 106-179, 114 Stat. 46-47.
} 
Today, Section 81 requires the Secretary of Interior or the Secretary's designee to approve any contract that encumbers Indian lands for a period of 7 years or more. Pursuant to 25 CFR $\S 84.002$, leasehold mortgages, easements, and any other contract that gives a third party exclusive or nearly exclusive proprietary control over tribal land are governed by Section 81 . Approvals are normally made by the regional or area BIA office responsible for the particular tribal lands.

\section{SPECIAL CONSIDERATIONS FOR LEASES ON TRIBAL LANDS}

The considerations for contracts discussed in this Chapter 6 are also critical for leases of tribal lands. Reaching agreement on lease issues is a critical earlystage development issue due to the importance of site control in permitting, negotiations for PPA's, transmission interconnection, and financing. While the lease does not need to be negotiated too early in the process, the joint venture or development agreement should guide the tribe and non-tribal parties through general goals of a project site lease to avoid surprises during the development process.

$>$ Talk with the local BIA officials early about the approval process, timelines, federal appraisal requirements, etc.;

$>$ Permitted uses: ancillary uses and projects enabled by the primary project may be very valuable to the tribe; the tribe should carefully draft the permitted uses in the lease to preserve valuable uses that are not essential to the success of the project;

$>$ Compensation, alternative tax structure: there are many ways to structure compensation, royalties and tax payments within the requirements of federal law;

$>$ Term (primary and renewal): if a non-tribal entity requires ownership for debt or tax purposes, once these purposes are satisfied the tribe should be able to come into significant or majority ownership, even if this requires phasing over a period of years;

$>$ Assignment and transfer: some type of pre-approved authorization is common for those entities who may take a security interest (e.g., approved encumbrances); 
Removal of improvements; reserve account: consider requiring the developer to fund a reserve account, which can be accomplished without tying up liquid assets by using a letter of credit, personal guarantees, or other devices; and

$>$ Dispute resolution: issues of sovereign immunity, choice of law, choice of forum for resolving disputes, and exhaustion of tribal remedies must be addressed; the ultimate goal is to try and solve the problem while keeping the project operating or moving forward. Refer to the discussion in Chapter 5 for a more detailed discussion of these topics.

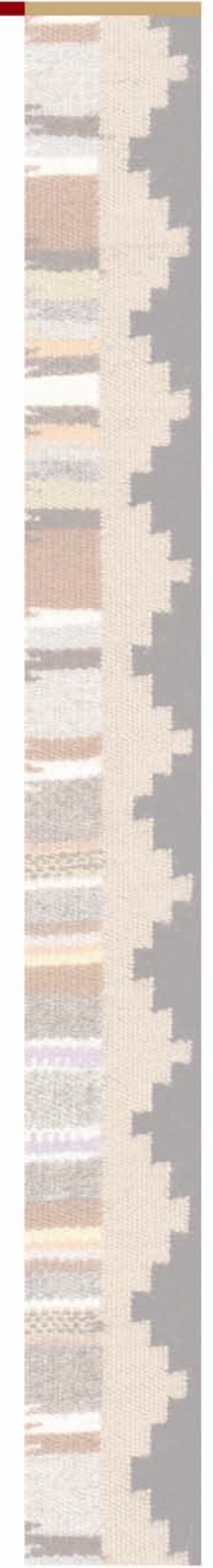




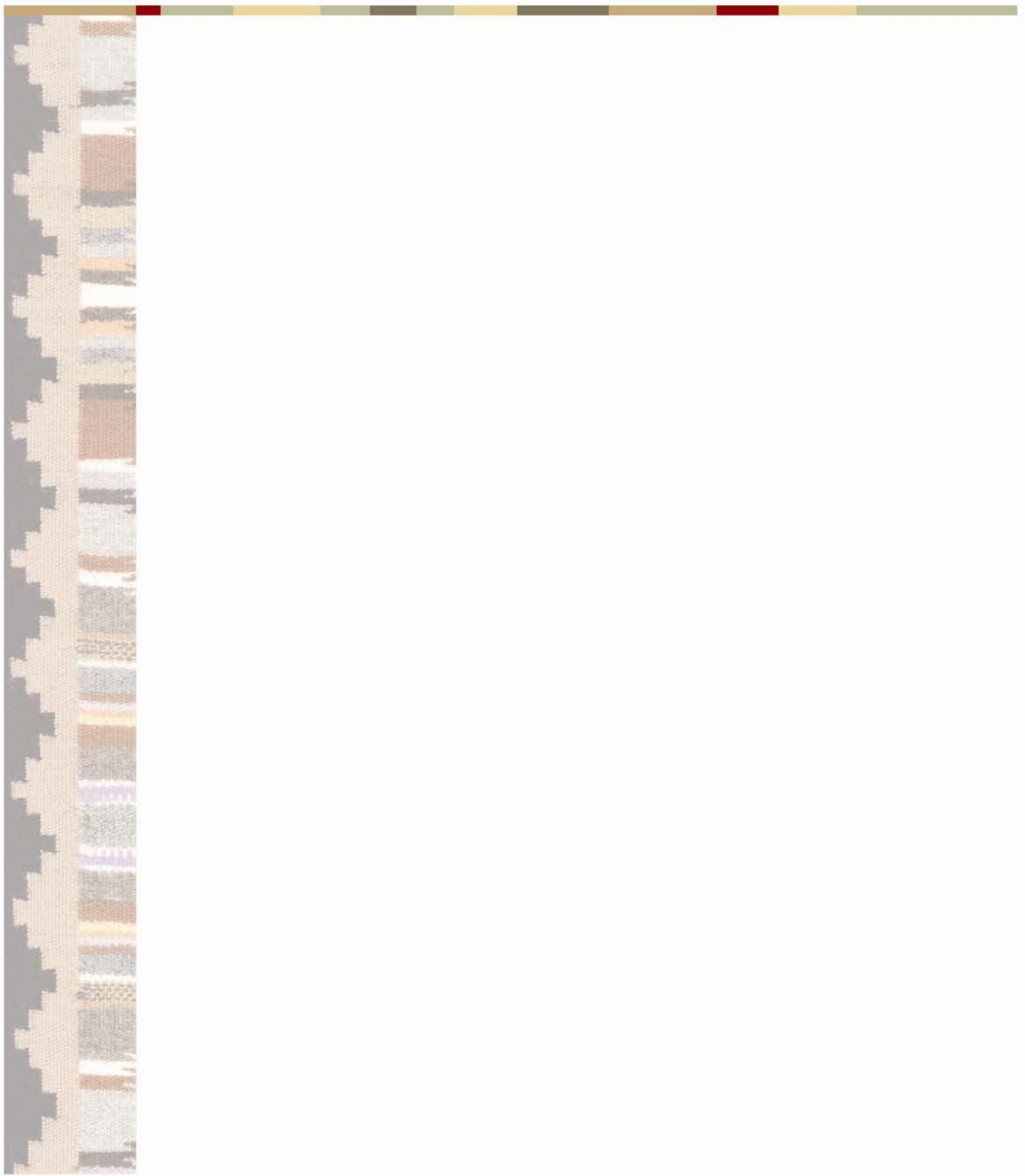


As discussed in previous chapters there are several stages in the development of a renewable energy project. Funding the cost of a renewable energy project also will likely occur in stages, and different sources of funding may be necessary or available depending on the stage of the project. Funding for preconstruction development costs may come from a variety of sources, including the tribe, debt, grants, or a joint development arrangement with another party willing to fund such costs.

While the tribe or developer is completing the pre-construction development process, it will need to obtain funding for the construction and startup costs of the project. Funding for the construction and startup costs is often available in a variety of forms and can include funding by the tribe, debt, equity investments, grants, RECs, federal and state tax credits and other governmental incentives. Renewable energy projects will often include a combination of multiple sources of funding. The particular financing or combination of sources of financing and terms and conditions of such financing varies from project to project depending on a variety of factors. Those factors include current market conditions, the expected performance of the project, whether there is a firm commitment to purchase the power generated by the project, the credit of the power purchaser, the credit and collateral of the borrower, the availability of state and federal incentives, the size of the project and the experience of the tribe and any development partners with similar projects. As discussed later in this Chapter, participation by a tribe or other tax-exempt party in the ownership of the project can result in limitations on the availability of certain incentives like tax credits and depreciation. The following is a discussion of some of the potential sources of funding for a renewable energy project.

\section{PAY AS YOU Go}

It is possible to fund a renewable energy project out-of-pocket. A tribal government could determine that the profits of a separate venture should be spent 
to develop the tribe's energy resources and provide another measure of selfsufficiency. While this approach avoids issues relating to non-tribal ownership of the finished project, it may not be feasible given the large capital expenditure involved in planning, developing and operating a renewable energy project. In addition, this approach will divert large amounts of money from other opportunities being pursued by the tribe and may require foregoing funding available through tax incentives, costing the tribe more financially than would the sale of equity in the project or the incurrence of debt.

\section{DEBT FINANCING}

\section{BANK DEBT}

Another option for obtaining project financing is to incur debt from a bank. Bank debt is preferable to the sale of equity if maintaining ownership of the project is important to the tribe. The bank issuing the debt does not obtain a property interest in the project (the bank may have a lien on the project's assets as described below), nor will the bank have a right to control the management and day-to-day operations of the project. Upon full repayment of the loan, the relationship between the bank and the project will expire.

In addition, issuance of a promissory note to a bank does not require compliance with state and federal securities laws, which reduces both the time involved in obtaining the funds and the advisory fees. Finally, a borrower can generally pre-pay a bank loan without payment of a penalty. This means that if, during the life of the loan, the tribe decides it has enough cash on hand to repay the loan or finds financing on better terms than the outstanding bank debt, it can repay the loan without incurring additional costs.

Bank debt may, however, have floating rates of interest. This means that the interest rate can change over the life of the loan, making it more difficult to plan for repayment. In addition, bank debt is generally payable in a shorter time than bonds, as discussed below. 
Bank debt is often secured. This means that the bank places a lien on the assets of the entity or the project. If the borrower fails to pay back the loan, the bank can exercise its rights under the lien and take possession of the assets subject to the lien or sell them to the highest bidder. With respect to a renewable energy project, a lien could be granted against all assets of the entity, specified equipment, the amounts due under a power sales agreement or a combination of these.

\section{CONVENTIONAL LOANS}

Bank debt can take several forms. One common form of bank debt is term debt. Under this form of loan, the bank would disburse the full amount borrowed at the outset. Principal and interest would be payable within a specified time. Interest on these loans begins to accrue on the full amount due from the disbursement date.

\section{LINES OF CREDIT}

Lines of credit are also common forms of debt financing. Under a line of credit, the borrower could request that the bank disburse certain amounts of the available credit over the life of the loan. For example, if a line of credit for $\$ 10$ million was obtained, the tribe could request a disbursement of $\$ 3$ million in the first year to pay for certain project expenses due that year. It could request an additional $\$ 5$ million in the second year to pay for project expenses due in the second year.

A line of credit is an attractive option where expenses will be staged over time. The benefit to taking smaller draws against the loan is that interest only accrues on the amount actually borrowed. In the above example, this means that interest would only accrue on the $\$ 3$ million draw during the first year, rather than on the full $\$ 10$ million line of credit amount.

\section{BONDS}

Another financing option is the issuance of bonds. As with bank debt, bonds are a form of debt incurred by the entity. The loan is made not by one or a 
small group of banks, but by a number of investors. Holders of bonds would not have rights to participation in the management of the project entity, nor would they have an ownership interest in the profits of the project. Instead, as with bank debt, bondholders would have a right to payment of principal and interest.

Bonds are different than bank debt in that the investors have an indirect relationship with the entity issuing the bonds. The relationship between the investors or bondholders and the issuing entity will be indirect because the bondholders are generally represented by a trustee. During the life of the bonds, the issuing entity provides information and communicates only with the trustee, rather than with the individual bondholders.

Generally, bonds have much longer maturity dates than bank debt. Bonds can remain outstanding for 20 years before repayment is due. Bonds also generally have fixed rates of interest, making the repayment obligation easier to calculate. Unlike bank debt, however, bonds often contain a prohibition on pre-payment. Therefore, once incurred, the tribe's obligation may extend for a long period, often outlasting the tribal government that approved their issuance.

Bondholders often expect that they will be able to transfer or sell the bonds. As with shares, a tribe issuing bonds must comply with state and federal securities laws. While a tribe can make use of exemptions from the securities laws by selling bonds only to institutional and accredited investors within specified limits, thereby reducing the expense of a public offering of securities, the bonds issued will not be freely tradable by the bondholders. This will obviously affect the financial terms that the investors are willing to accept. For example, unregistered tribal bonds would likely carry higher rates of interest than bonds issued by a state or municipal government.

\section{TAX-EXEMPT DEBT}

In certain instances both bank debt and bonds can be issued on a taxexempt basis. This means that the bank lending the money or the investors purchasing bonds will generally not pay taxes with respect to interest payments 
received. If the debt can be issued on a tax-exempt basis, the lenders, whether a bank or bondholders, will generally make loans at lower rates of interest than would otherwise be available. As a general rule, tribes are permitted to issue taxexempt debt if all of the proceeds are used in the exercise of an essential governmental function. There are a number of additional requirements and restrictions related to the issuance of tax-exempt debt that must be analyzed with respect to each project.

\section{CURRENT BUT SHORT-LIVED FINANCING INCENTIVES}

The American Recovery and Reinvestment Act of 2009 (ARRA) included a number of provisions intended to support the development of projects, including renewable energy projects developed by tribes. These provisions include tribal economic development bonds, clean renewable energy bonds, Build America bonds and qualified energy conservation bonds. The following is an overview of each of these bonds.

\section{Tribal Economic Development Bonds}

Tribal economic bonds expand the permitted use of bonds issued by a tribe by removing the essential governmental function test and treating the bonds as if they were issued by a state. This expands the scope of renewable energy projects eligible for tax-exempt financing by a tribe. The amount of tribal economic bonds that can be issued by tribes is limited by a $\$ 2$ billion cap that is required to be allocated among tribes by the Secretary of Treasury in consultation with the Secretary of the Interior. ${ }^{44}$ Tribal economic development bonds may not be issued for facilities that house or that are used in the conduct of gaming or for facilities that are located outside the Indian reservation.

\footnotetext{
${ }^{44}$ The IRS issued Notice 2009-51 on June 5, 2009 to detail how tribes can apply for TEDBs, when applications are due, the types of projects that can be financed, and how the volume cap will be spread across Indian country. The IRS Notice explains that the $\$ 2$ billion will be distributed in two separate $\$ 1$ billion releases (also called "tranches"). The application for the first tranche was due on August 15, 2009. Applications for the second tranche were due by January 1, 2010. Any tribe that applies must be prepared to issue the bonds by December 31, 2011. If the tribe cannot issue its bonds by the deadline, it will forfeit its allocation back to the IRS.
} 


\section{Clean Renewable Energy Bonds}

Governmental bodies, including Indian tribal governments, are also eligible to issue new clean renewable energy bonds ("CREBs") to finance qualified renewable energy facilities. The advantage of a CREB is that the federal government effectively pays a portion of the issuer's interest expense through a federal tax credit available to the bondholders in lieu of interest. A "qualified renewable energy facility" includes a wind facility, closed-loop biomass facility, open-loop biomass facility, geothermal or solar energy facility, small irrigation power facility, landfill gas facility, trash facility and marine and hydrokinetic renewable energy facilities owned by an Indian tribal government or any political subdivision thereof. The aggregate amount of CREBs that can be issued is capped and required to be allocated among issuers by the Secretary of Treasury. The ARRA increased the cap on CREBs by $\$ 1.6$ billion, with one third of that increase allocated to state, local and Indian tribal governments. To receive an allocation of CREBs, an issuer must file an application with the Internal Revenue Service. The application for the most recent allocation of CREBs was due August 4, 2009. Recent guidance regarding the CREB program is provided in IRS Notice 2009-33.

The 2010 Hiring Incentives to Restore Employment Act ("HIRE Act”), signed by President Obama on March 18, 2010, permits issuers of new CREBs (as defined in IRC $\$ 54 C$ ) to receive a cash payment from the federal government in lieu of a tax credit. The cash payment is equal to the lesser of (i) the amount of interest payable under the bond, or (ii) $70 \%$ of the amount of interest which would have been payable under the bond if the interest were determined at the applicable credit rate published by the U.S. Treasury Department for the date the bonds were sold. The cash payment option applies to CREBs issued after March 18, 2010.

\section{Build America Bonds}

Build America Bonds are a new type of tax credit bond that tribes can use instead of tax-exempt bonds. The lender is eligible for a tax credit equal to $35 \%$ of the amount of interest payable by the tribe. In lieu of the lender receiving a tax credit, the tribe may qualify to elect to receive a cash payment in the same amount. Build America Bonds may be available for development of tribal energy projects. 
Build America Bonds are subject to certain restrictions, including the following: (1) the bonds must be issued during 2009 and 2010; (2) bond proceeds cannot be used by or loaned to private parties; and (3) the bonds cannot be used for refinancings.

\section{Qualified Energy Conservation Bonds}

Governmental bodies, including Indian tribal governments, are eligible to issue qualified energy conservation bonds if 100 percent of the available project proceeds are used for one or more qualified conservation purposes.

Like CREBS, qualified energy conservation bonds are tax credit bonds, where the issuer repays the principal amount of the bonds plus a portion of the interest and the bondholder receives federal tax credits in lieu of the remaining interest.

The 2010 HIRE Act also permits issuers of qualified energy conservation bonds to receive a cash payment from the federal government in lieu of a tax credit. The cash payment is equal to the lesser of (i) the amount of interest payable under the bond, or (ii) $70 \%$ of the amount of interest which would have been payable under the bond if the interest were determined at the applicable credit rate published by the U.S. Treasury Department for the date the bonds were sold. The cash payment option applies to qualified energy conservation bonds issued after March 18, 2010.

"Qualified conservation purposes" includes the production of electricity from renewable energy resources, such as wind, closed-loop or open-loop biomass, geothermal or solar energy, small irrigation power, landfill gas, trash or marine and hydrokinetic renewable energy facilities. In addition, tribes must use qualified energy conservation bonds for projects that would otherwise qualify for tax-exempt financing. The ARRA increased the volume cap on qualified energy conservation bonds from $\$ 800$ million to $\$ 3.2$ billion. The volume cap is allocated among the states based on population. Large local governments within a state (which includes 
Indian tribal governments) are then allocated a portion of such volume cap. based on population within the state.

\section{New Markets Tax Credit Financing}

While beyond the scope of this Handbook, financing through the New Markets Tax Credit Program may be available for all or part of a trial renewable energy project. The New Markets Tax Credit Program is a federal program designed to encourage investment in underserved communities.

\section{EQUITY FINANCING}

A developer of a renewable energy project will often seek equity investments to fund all or part of the project costs. Typically, an equity investor acquires an ownership interest in the entity that owns the project in exchange for a contribution of cash or property to the entity. The number of equity investors and terms of the equity investments vary from project to project and often involve significant negotiation among the parties. The terms of an equity investment will also vary depending on the objectives of the investor. For example, some equity investors are primarily focused on obtaining the benefit of tax credits and depreciation generated by the project. Other equity investors are less interested in the tax attributes of the project and are looking for a cash return on their investment. The developer of a project may also want to retain an equity interest in the project in exchange for its development activities.

The form of legal entity used to own the project — and in which the equity investors acquire an ownership interest - will vary from project to project and could include a corporation, general partnership, limited partnership, or LLC. In the case of a corporation, equity would be in the form of shares. In the case of a partnership (whether a general partnership or a limited partnership), equity would be in the form of partnership interests. In the case of a limited liability company, equity would be in the form of membership interests. 
In many renewable energy projects, particularly projects with tax credit investors, the project entity will be organized as a pass through entity for tax purposes - meaning the income or gain of the entity is not taxable to the entity and instead the income or gain passes through to the owners of the entity. General partnerships, limited partnerships and LLCs are generally treated as pass through entities for federal income tax purposes. An LLC is probably the most common form of pass through entity used in current transactions. Finally, even if the project is located on tribal land and includes tribal ownership, outside equity investors will often insist that the project entity be organized under state law rather than tribal law.

If the project entity is organized as an LLC, the owners of the LLC will enter into an "operating agreement" or "limited liability company agreement" (referred to herein as the "LLC Agreement") in connection with the acquisition of an equity interest in the LLC. The LLC Agreement will typically govern many of the material terms and conditions related to the ownership of an equity interest in the LLC, including the following:

Contributions to be made by each of the owners, including contributions of cash or property and the timing of such contributions.

$>$ Allocations of profits, losses and tax credits of the LLC among the owners of the LLC.

$>$ Distributions of cash flow to the owners of the LLC.

$>$ Governance of the LLC. LLCs provide a lot of latitude to the owners for purposes of determining the governance of the LLC. Certain decisions may require approval of a majority or larger percentage of the owners with voting rights. Other decisions may only require the approval of a manager or a board. Finally, certain day to day decisions and activities may be carried out by officers or other agents of the LLC.

$>$ Method for record keeping, accounting and other financial matters.

$>$ Restrictions on transfers of equity interests in the LLC. 
Dispute resolution mechanisms and governing law provisions.

The above is only a summary of certain material terms often included in an LLC Agreement. The acquisition and ownership of an equity interest in an LLC or other project entity will often involve a number of other agreements and terms.

\section{VALUATION}

In order to raise capital for a project through equity, the tribe and its advisors should determine the value of shares in the project. The price at which equity interests are sold depends on a number of factors including not only the perceived value and revenue potential of the completed project, but also the rights to be held by owners and the percentage interest to be sold. A class of equity with very limited voting rights will likely be less valuable than those with greater voting rights. Similarly, an investor's opportunity to control a small minority interest in the entity, say $10 \%$ or less, will be deemed less valuable than a larger stake to the same investor.

\section{SEARCH FOR INVESTORS}

Once the price at which equity will be sold is determined, the project must find willing investors. In finding investors the tribe and its advisors must take particular care to comply with federal and state securities laws. The issuance of a security (of which a share of a corporation or interest in an LLC is one type) by a tribe is not automatically exempt from these laws. In general, the most cost effective way to ensure compliance with these laws is to limit investment to so called "institutional" or "accredited" investors. These are investors that have large pools of funds available for investment and are knowledgeable and sophisticated with respect to investment. Exemptions from both federal and state securities laws are often available if the vast majority of investors in the project are these types of institutional or accredited investors.

\section{INFORMATION REQUIREMENTS}

Often investors will require particular information regarding plans for the project. Such information can include for example, studies conducted during the 
project development process, forward-looking financial statements, descriptions of the rights of shareholders and the managers of the entity. Any written information provided must also include a description of all risks of the project.

The information is usually presented in the form of an investor presentation or memorandum that is provided to a prospective investor only after the investor has signed a non-disclosure or confidentiality agreement. Often the project's developers will make presentations to potential investors highlighting the project opportunities and risks.

To comply with federal and state securities laws any information that is provided to prospective investors must accurately disclose all information that is important in making an investment decision. An entity's accounting and legal advisors should be involved in reviewing the disclosure documents and ensuring compliance with these requirements.

\section{TAX CREDITS AND OTHER INCENTIVES}

Congress has enacted several incentives to encourage the development of renewable energy projects. These incentives include tax credits, grants in lieu of tax credits, accelerated depreciation of project costs, loan guarantees, and subsidies for debt financing. The following is a summary of certain federal incentives intended to encourage the development of renewable energy projects. Each incentive is subject to certain requirements and limitations. In addition, many of these incentives are further limited or unavailable when the project is owned or operated by a tax-exempt party, including an Indian tribal government. The following sections discuss many of the federal incentives currently available for renewable energy projects and some of the limitations on such incentives.

\section{Production Tax Credit}

Section 45 of the Internal Revenue Code ("IRC") provides a production tax credit (PTC) upon the sale of electricity produced from certain qualified energy resources like wind, biomass, geothermal and solar. The PTC is available during 
the ten-year period (five years in some cases) beginning on the date the qualified facility is placed in service. ${ }^{45}$ The PTCs can be used to offset the federal income taxes of the owner of the facility on a dollar-for-dollar basis. If the facility is owned by a partnership (or entity taxed as a partnership, like an LLC) then the PTCs generated by the facility will generally pass through to the partners.

The amount of the PTC is adjusted each year. In 2008, the PTC was 1 cent per kilowatt hour for open-loop biomass facilities, small irrigation power facilities, landfill gas facilities, trash facilities, qualified hydropower facilities and marine and hydrokinetic renewable energy facilities.

In 2008, the PTC was 2.1 cents per kilowatt hour for wind facilities, closed-loop biomass facilities, geothermal or solar energy facilities, refined coal production facilities and Indian coal production facilities.

To qualify for the PTC, the electricity must be produced by the taxpayer's project from qualified energy resources at a qualified facility. In addition, the electricity must be sold by the taxpayer to an unrelated person. ${ }^{46}$

"Qualified energy resources" include wind, closed-loop biomass, openloop biomass, geothermal energy, solar energy, small irrigation power, municipal solid waste, hydropower production and marine and hydrokinetic renewable energy. ${ }^{47}$ Generally, a "qualified facility" is a facility that produces electricity from qualified energy resources and satisfies certain other requirements set forth in Section 45 , including a requirement that the qualified facility is completed and placed in service by certain dates. ${ }^{48}$

The ARRA extends the period that a qualified facility must be completed and placed in service. Wind projects will now qualify for PTCs if placed in service by December 31, 2012. Biomass, geothermal, landfill gas, trash, qualified hydro

${ }^{45}$ IRC $\S \S 45(a)$ and $45(b)$.

${ }^{46}$ IRC $\S 45(a)$.

${ }^{47}$ IRC $\S 45(c)$.

${ }^{48}$ IRC $\S 45(d)$. 
projects and marine and hydrokinetic renewable energy projects will now qualify if placed in service by December 31, 2013.

The PTC is subject to phaseout and certain adjustments and limitations. If a facility is also financed through certain grants, tax-exempt financing or other credits, then Section 45 reduces the PTC. The adjustments, limitations and phaseout should be carefully analyzed with respect to each project.

If a project is eligible for both PTCs and Investment Tax Credits, then the project owner must choose which credit to take with respect to the project.

\section{INVESTMENT TAX CREDIT}

Section 48 of the Internal Revenue Code provides a tax credit for certain types of renewable energy property, including solar systems and combined heat and power systems. The tax credit provided under IRC Section 48 is referred to as an energy credit or an investment tax credit (ITC). Like the PTC, the ITC can be used to offset the federal income taxes of the taxpayer receiving the credit on a dollarfor-dollar basis. With respect to solar and certain other property, the ITC is equal to 30 percent of the taxpayer's cost basis in the property. ${ }^{49}$ With respect to combined heat and power system and certain other property, the ITC is equal to 10 percent of the taxpayer's cost basis in the property. ${ }^{50}$ One significant difference between the ITC and the PTC is that the entire amount of the ITC is available to the taxpayer in the year the energy property is placed in service, whereas the PTC is available over a ten-year period (five years in some cases) as electricity is produced and sold by the project owner.

If an ITC is claimed with respect to a project and the project is disposed of or otherwise ceases to be investment credit property within the five-year period after the project is placed in service, then all or part of the ITC is subject to recapture - meaning the tax payer that claimed the ITC must include all or a

\footnotetext{
${ }^{49}$ IRC $\S 48(a)$.

${ }^{50}$ IRC $\$ 48(a)$.
} 
portion of the previously claimed credit as income. ${ }^{51}$ A project eligible for an ITC can be leased to another party, and the lessor can still qualify for the ITC.

However, if the project is leased to a tax-exempt party, then it will not qualify for the ITC. ${ }^{52}$ This can be a material issue in structuring an ITC transaction involving a tribe.

The ARRA amended IRC Section 48 to permit a wind facility to take a 30 percent ITC in lieu of PTCs. To qualify, the facility must be placed in service between 2009 and 2012. Since the PTC is based on energy sold and the ITC is based on the cost of the project, each project will have to analyze which credit will generate the most value for the project.

\section{GRANTS IN LIEU OF TAX CREDITS}

Section 1603 of the American Recovery and Reinvestment Act of 2009 permits projects that would otherwise qualify for PTCs or ITCs to claim a cash grant from the U.S. Treasury in lieu of the tax credit. The amount of the grant is $30 \%$ of the cost of certain qualified facilities, including wind, biomass and solar facilities and $10 \%$ with respect to certain other qualified facilities. To qualify for the grant, construction on the qualified facility must begin in 2009 or 2010 and the facility must be placed in service by the date required to qualify for PTCs or ITCs, as applicable. The grant eliminates the need to find investors that can use tax credits. Unfortunately, this grant is not available to projects owned by any federal, state or local government, including an Indian tribal government, a tax-exempt organization described in IRC $\S 501(\mathrm{c})$, or any partnership or other pass-through entity of which any of the foregoing is a partner or holder of an equity interest. Thus, if a tribe is an owner of the project or participates in the ownership through a partnership, then the project will not be eligible for the grant. Guidance released by the U.S. Treasury Department in July of 2009 provides that this limitation can be eliminated by having the tribe or other tax-exempt party own its interest in the Project through a taxable corporation.

\footnotetext{
${ }^{51}$ IRC $\S 50(\mathrm{a})$.
}

${ }^{52}$ IRC $\S 50(b)$. 


\section{ACCELERATED DEPRECIATION}

Property used in renewable energy projects, like wind and solar projects, is generally eligible for a five-year MACRS depreciation recovery period. ${ }^{53}$ In addition, in 2008, taxpayers were permitted to deduct $50 \%$ of the cost of certain "qualified property" acquired and placed in service during the year ("bonus depreciation"), in addition to regular depreciation on the remaining cost of the property. This allowed in excess of $50 \%$ of the cost of qualified property to be deducted in 2008. Qualified property includes property that has a recovery period of 20 years or less, like wind turbines, solar panels and other equipment. The ARRA extended bonus depreciation to qualified property acquired and placed in service in 2009.

If a renewable energy project is leased to a tax-exempt entity-for example, a sale-leaseback transaction with a tribe as the lessee-then the property will be classified as "tax-exempt use property" and will no longer be eligible for fiveyears MACRS depreciation. ${ }^{54}$ Instead, the property will be required to be depreciated under the alternative depreciation system using straight line method over the class life of the property. ${ }^{55}$ If property is leased to or owned by a partnership (or limited liability company taxed as a partnership) with a tax-exempt partner, like a tribe, then a portion of the property will be treated as tax-exempt use property. ${ }^{56}$ The portion of the property treated as tax-exempt use property is equal to the largest ownership interest the tax-exempt partner will have in the partnership's items of income or gain during the life of the partnership. ${ }^{57}$ The loss of accelerated depreciation will make the project less attractive to investors interested in the tax attributes of the project.

\footnotetext{
${ }^{53}$ IRC $\S 168$.

${ }^{54}$ IRC \& 168(h).

${ }^{55}$ IRC $\S 168(\mathrm{~g})$.

${ }^{56}$ IRC $\S 168(\mathrm{~h})$.

${ }^{57}$ IRC $§ 168(\mathrm{~h})$.
} 


\section{Deal Structures for Obtaining the Benefit of TAX CREDITS, DEPRECIATION, AND OTHER INCENTIVES}

Developers of renewable energy projects are often unable to fully utilize PTCs, ITCs or depreciation generated by a project. Likewise, Indian tribal governments, tribal enterprises, and other tribal organizations not subject to federal income tax have no need for PTCs, ITCs, or depreciation. Federal tax rules do not currently allow the owner of a project to simply transfer a PTC or ITC to a third party in exchange for a cash payment. Fortunately, a number of structures have emerged that allow the developer of a renewable energy project to monetize the value of PTCs, ITCs, and depreciation generated by the project. These structures include the following: a partnership between the developer and an investor with a need for tax credits and depreciation (a "partnership flip" structure); a sale of the project immediately followed by a lease back to the developer (a "sale-leaseback" structure); or a sale of the project to another party with a royalty, lease, development fee, and/or other payments to the developer. This final structure can also include a PSA between the project owner and the developer. These structures are complex and subject to a number of requirements and limitations under federal tax rules. In addition, these structures are subject to further limitations when a governmental or tax-exempt party, like an Indian tribal government, tribal enterprise, or other tribal organization not subject to federal income tax, desires to participate in the ownership of the project. The following is a general discussion of some of the structures used to monetize ITCs, PTCs, and depreciation, including an overview of how such structures might be used when a tribe is involved in the project.

\section{PARTNERSHIP FLIP STRUCTURE}

Under a partnership flip structure, the renewable energy project is owned by an entity taxed as a partnership for federal income tax purposes, such as a partnership, limited partnership, or limited liability company (referred to herein as a "partnership"). A party with a need for tax credits (referred to herein as a "tax credit investor") makes a cash investment in the partnership in exchange for an equity interest in the partnership. The developer of the project also retains an 
equity interest in the partnership. In exchange for its cash investment, the tax credit investor is initially allocated substantially all of the profits, losses and tax credits generated by the partnership until the tax credit investor achieves a negotiated return on its investment, taking into account the value of the tax credits, depreciation and cash flow.

After the tax credit investor has achieved its negotiated return, the ownership interests in the partnership automatically flip and the developer and other equity investors are allocated substantially all of the profits and losses generated by the partnership. Following the flip in equity interests, the developer typically has an option to acquire the tax credit investor's remaining equity interest in the partnership.

There are a number of variations on the partnership flip structure, and the particular terms of each arrangement will vary depending on the economics of the particular project, sources of funding and the business objectives of the parties involved. In 2007, the IRS issued Revenue Procedure 2007-65, which provides guidelines and a safe harbor for structuring a partnership flip transaction for a wind project.

Unfortunately, federal tax rules provide that if a tax-exempt party, like an Indian tribal government, a tribal enterprise, or other tribal entity not subject to federal income taxation, is a partner in a partnership, then a portion of the property owned by the partnership will be treated as tax-exempt use property subject to longer depreciation periods. ${ }^{58}$ The portion of the property treated as tax-exempt use property is equal to the largest ownership interest the tax-exempt partner will have in the partnership's items of income or gain during the life of the partnership. Tax-exempt use property treatment will substantially increase the depreciation period for the property owned by the project and reduce the amount of investment a tax credit investor is willing to make in the project.

\footnotetext{
${ }^{58}$ IRC $\S \S 168(\mathrm{~g})$ and $168(\mathrm{~h})$.
} 


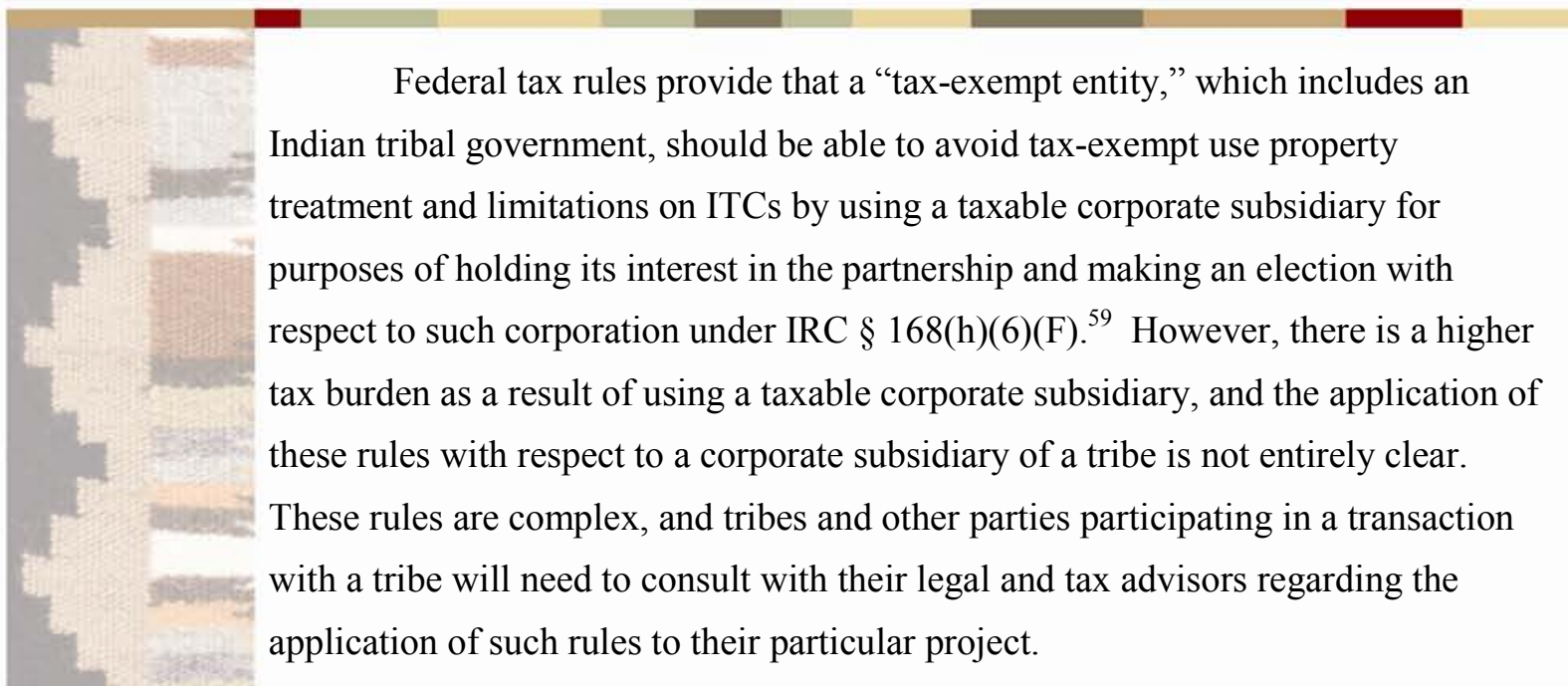

${ }^{59}$ IRC $\S 168(\mathrm{~h})$. IRC $\S 168(\mathrm{~h})(6)(\mathrm{F})$ provides that by making an election under $\S 168(\mathrm{~h})(6)(\mathrm{F})$ with respect to a corporate subsidiary of a tax-exempt entity, any sale of the stock in the corporation and any dividends or interest received by the tax-exempt entity from the corporation will be subject to federal income taxation." 


\section{Partnership Flip Structure}

\section{Pre-Flip}

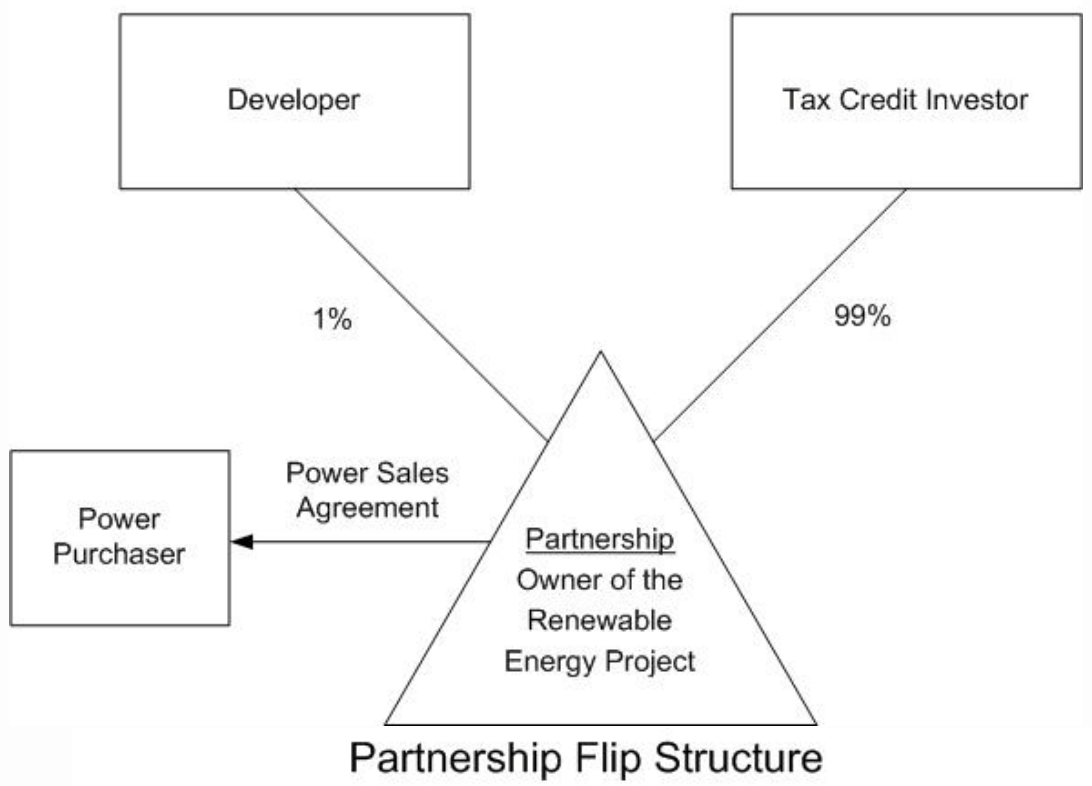

\section{Post-Flip}

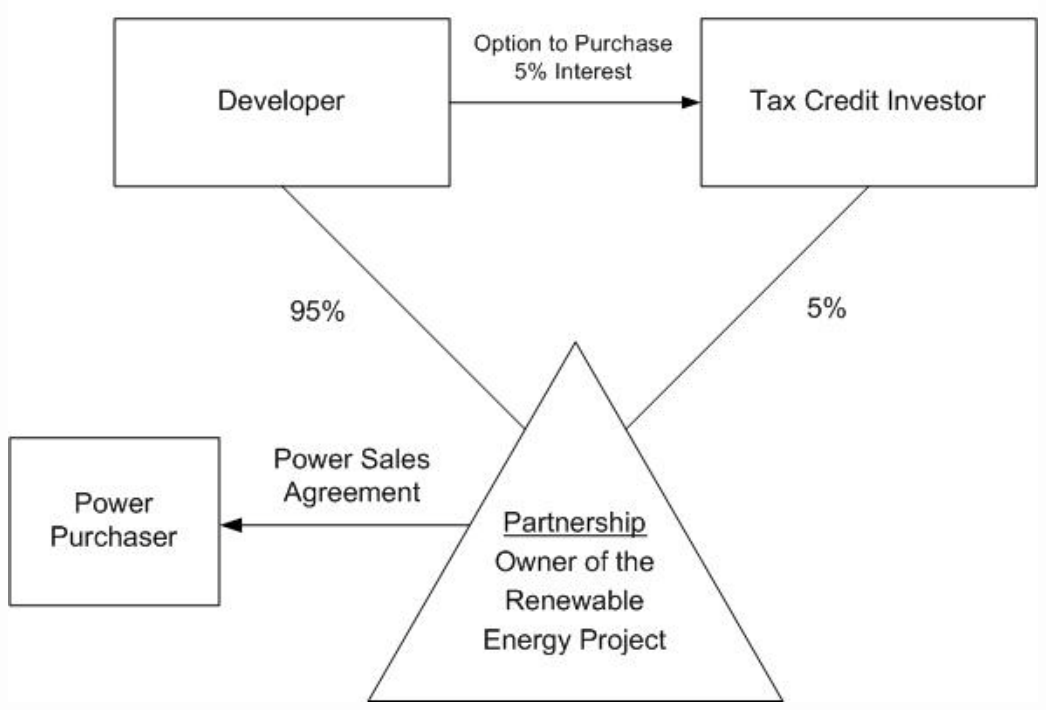




\section{SALE-Leaseback STRUCTURE}

Projects that qualify for ITCs may be able to utilize the partnership flip structure discussed above to monetize the ITC s and depreciation. Alternatively, the parties can utilize a sale-leaseback structure to monetize the ITCs and depreciation. PTCs in a wind project cannot be monetized through a sale leaseback transaction.

In a basic sale-leaseback transaction, the developer sells the project to the tax credit investor, and the tax credit investor immediately leases the project back to the developer. As the owner of the project, the tax credit investor is eligible for the ITCs and the depreciation deductions associated with the project, and the value of the ITCs and depreciation is taken into account when negotiating the arrangement between the parties. The sale of the project, including the transfer of the tax credits and depreciation, effectively monetizes the value of the tax credits and depreciation and provides a financing mechanism for a portion of the project. At the end of the lease the project developer will typically have the right to repurchase the project at fair market value. The terms of the lease must satisfy certain requirements under federal tax rules and be treated as a true lease for tax purposes, rather than as a financing arrangement. There are variations on this basic sale-leaseback structure.

Unfortunately, federal tax rules provide that if the project is leased to a tax exempt party, like an Indian tribal government, a tribal enterprise, or other tribal entity not subject to federal income taxation, then it will not qualify for ITCs and the leased property will be treated as tax-exempt use property subject to longer depreciation periods. ${ }^{60}$ A tribe may be able to avoid the limitations on ITCs and tax-exempt use property treatment by using a taxable corporate subsidiary to participate in the sale-leaseback transaction.

As discussed above, with respect to partnership flip transactions, the taxexempt use property rules and limitations on ITCs will also apply if the project is partially owned by a tribe or other tax-exempt party through an organization taxed

${ }^{60} \mathrm{IRC} \S \S 168(\mathrm{~g})$ and $168(\mathrm{~h})$. 
as a partnership, such as an LLC or limited partnership. Federal tax rules provide that a "tax-exempt entity," which includes a tribal government, should be able to avoid tax-exempt use property treatment and limitations on ITCs by using a taxable corporate subsidiary for purposes of holding its interest in the partnership and making an election with respect to such corporation under IRC $\S 168(\mathrm{~h})(6)(\mathrm{F}) .^{61}$

However, there is a higher tax burden as a result of using a taxable corporate subsidiary, and the application of these rules with respect to a corporate subsidiary of a tribe is not entirely clear at this time. These rules are complex, and tribes (and other parties participating in a transaction with a tribe) will need to consult with legal and tax advisors regarding the application of such rules to their particular project at the time of the discussions regarding the form of entity the tribe would like to use to develop the energy project.

\section{Sale-Leaseback Structure}

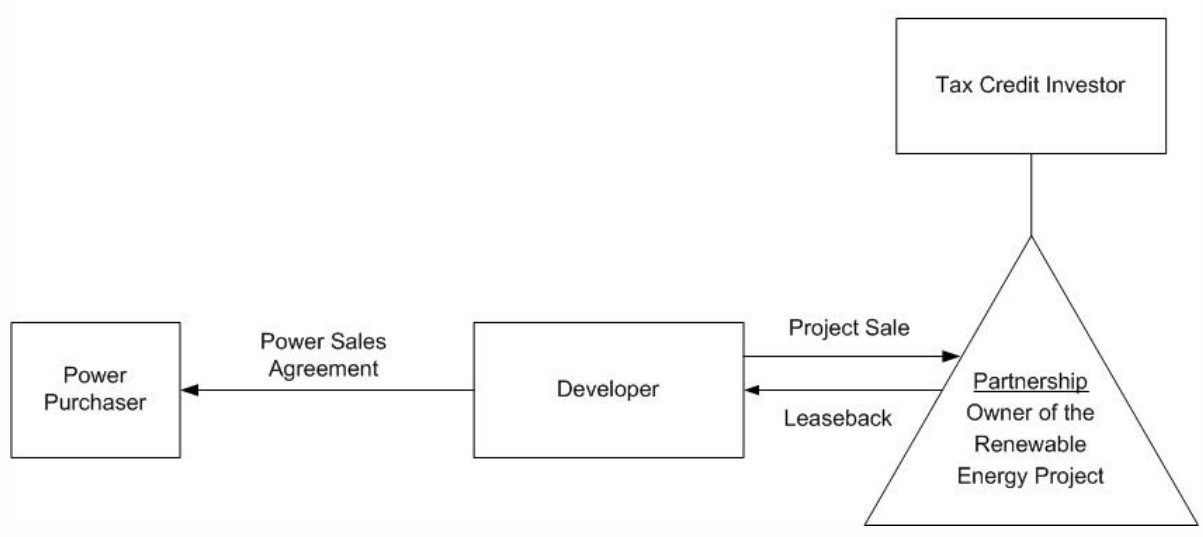

\section{Third Party OWNership OF THe ProJect}

Because of the limitations on tax credits and depreciation created by a taxexempt party's participation in a partnership flip or sale-leaseback transaction, another structure has emerged that removes the tribe or other tax-exempt entity from the ownership of the project (and provides for third-party ownership of the

${ }^{61}$ IRC $\S 168(\mathrm{~h})$. IRC $\S 168(\mathrm{~h})(6)(\mathrm{F})$ provides that by making an election under $\S 168(\mathrm{~h})(6)(\mathrm{F})$ with respect to a corporate subsidiary of a tax-exempt entity, any sale of the stock in the corporation and any dividends or interest received by the tax-exempt entity from the corporation will be subject to federal income taxation. 
project), thereby allowing the investors to take full advantage of the tax credits and accelerated depreciation. Variations on this third party ownership structure have been used by projects with tax-exempt parties, including tribal renewable energy projects.

Under this structure a tribe could participate in the development of the project, but sometime prior to placing the project in service, the tribe transfers ownership of its interest in the project to an unrelated party (project owner). The project owner then completes the development of the project and sells the power to an unrelated party and/or the tribe. Depending on the circumstances, the project owner may be primarily interested in the tax benefits of the project with no interest in long-term ownership. Alternatively, the project owner may be primarily interested in long-term ownership and operation of the project. In either case, the ownership of the project will typically be structured in a manner to monetize the value of the tax credits and accelerated depreciation.

The tribe could participate in this structure in several ways, including the following:

The tribe could negotiate a payment to recoup its development costs plus a development fee upon transferring the project to the project owner.

$>$ The tribe could enter into a lease with the project owner for any tribal land used in the project.

$>$ The tribe and the project owner could enter into an agreement providing for a royalty or other payment stream to the tribe based on the energy sold by the project. This payment stream may be linked to the use of tribal land.

$>$ The tribe may be able to provide certain services to the project owner. 
The tribe and the project owner could enter into a PSA providing for the purchase of power by the tribe. The tribe could use this power or sell it to a third party. ${ }^{62}$

$>$ The tribe or an entity partially or wholly owned by the tribe could finance a portion of the project by making a loan to the project owner. The loan must be made on terms and conditions that will support treatment as debt for tax purposes. This gives the project owner access to needed capital to construct the project and allows the tribe to participate in the project during the tax credit and depreciation period through interest payments.

Finally, the tribe and the project owner could enter into an agreement giving the tribe the right to acquire the project from the project owner after a certain period of time or upon certain events. Generally, the right to acquire the project will only be exercisable after the tax credits and depreciation associated with the project have been utilized by the project owner and any applicable tax credit recapture periods have expired.

One of the primary benefits of this third party ownership structure is that it removes the limitations and challenges created by having a tax-exempt party, like a tribe, involved in the ownership of the project. Either the project owner will have an appetite for the tax credits and depreciation generated by the project, or the project owner can monetize the tax credits and depreciation through a partnership flip transaction or a sale-leaseback transaction. However, a substantial drawback to this structure is the lack of tribal control.

\footnotetext{
${ }^{62}$ Under IRC $\S 7701$ (e), certain agreements for services, including agreements for the sale of power, will be treated as a lease of property if the agreement is determined to be a lease after taking into account all relevant factors. These rules will need to be carefully considered in any transaction where a tax-exempt party, including a tribe or another tax-exempt entity, is purchasing power. If the power sales agreement between the owner of the project and the tribe or another tax-exempt entity is treated as a lease, then the owner of the project will not be eligible for PTCs, ITCs, or accelerated depreciation deductions.
} 


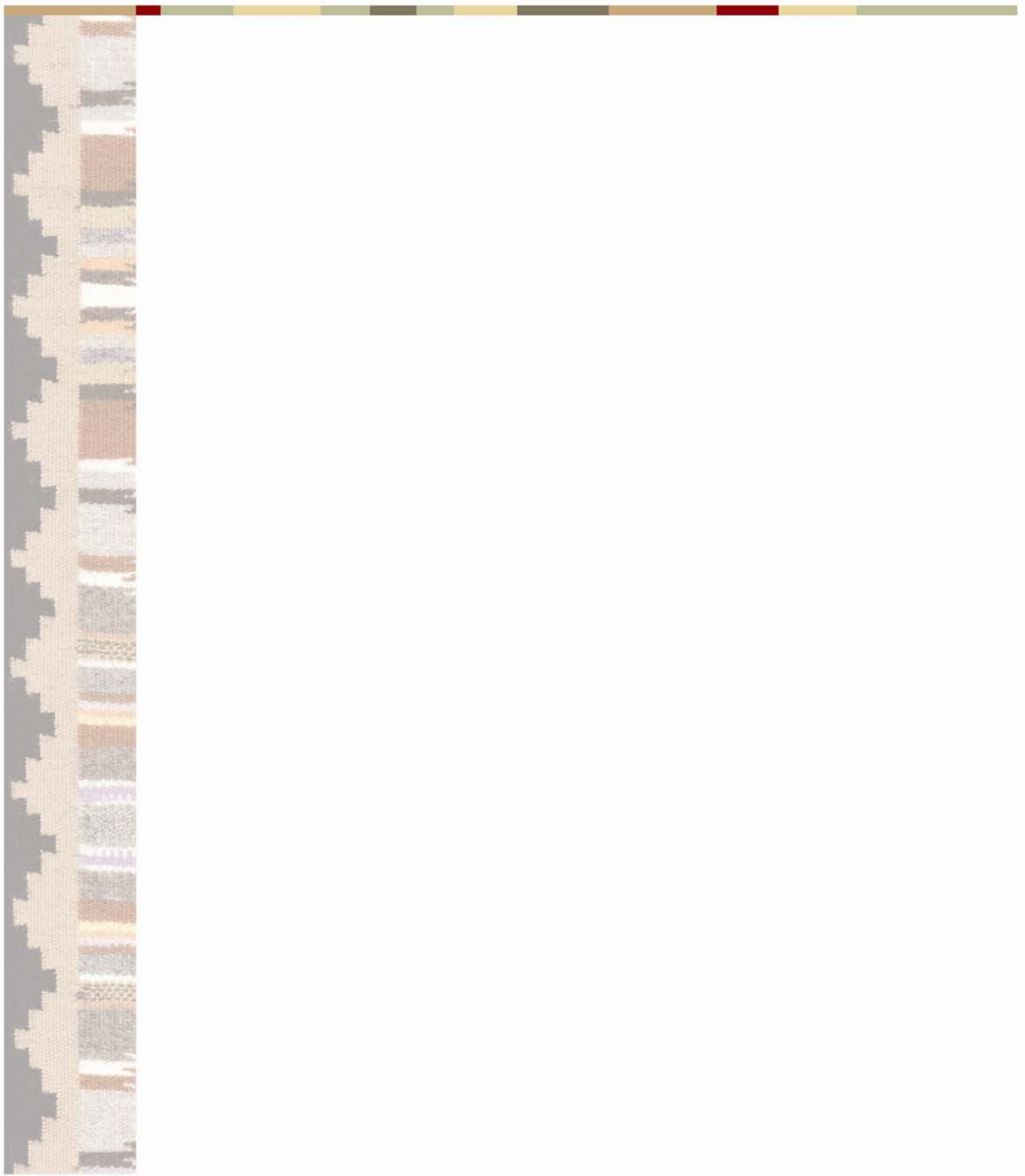




\section{CASE STUDIES - 2011 EDITION}

Evaluations of tribal renewable energy projects are underway for the 2011 Edition of this Handbook. If you are interested in submitting a case study for consideration, or know of a project that would make a good case study, please contact:

Douglas C. MacCourt, Chair, Indian Law Practice Group

Ater Wynne LLP

1331 NW Lovejoy St., Suite 900

Portland, OR 97209

Email: dcm@aterwynne.com

Phone: (503) 226-8672 or (503) 705-6031 (cell)

Fax: (503) 226-0079

Thank you. 

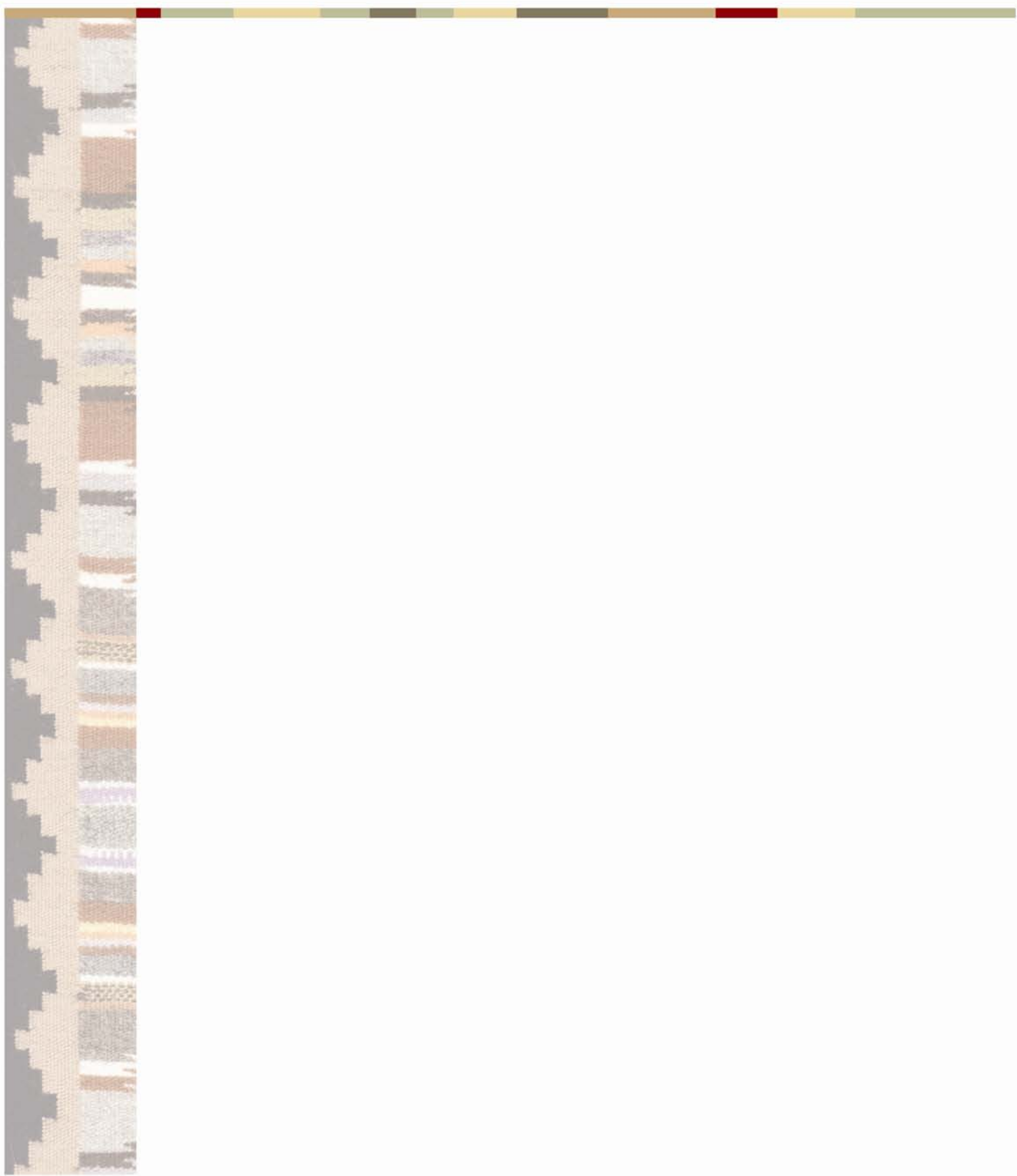


\section{GLOSSARY OF KeY ENERGY TERMINOLOGY}

The discussions in this Handbook will be easier to follow for readers familiar with the following basic terminology:

"Amp" or "Ampere" is the unit of electrical current and is analogous to a rate of flow of electrons (which for water is expressed in gallons per minute).

"ARRA" is the American Recovery and Reinvestment Act (ARRA) of 2009.

"Availability factor" is a similar concept to capacity factor, but reduces estimated output. The availability factor is an indicator of the reliability of the project and operates as a reduction in the potential capacity as a result of that reliability. In the case of a wind project, for instance, if turbines are down for maintenance or repair, they are not available for generating power even if the wind is blowing. The more maintenance and repairs that are necessary, the lower the availability of the project, the worse the availability of the project.

"Capacity factor" is the percentage of a year that a project is producing power. A large central-station coal plant might have a capacity factor close to 90 percent, a wind project is more typically around 25 percent. One cannot determine the available capacity of a power project by just adding the capacity of the turbines in the project. For example, $100 \mathrm{MW}$ of wind turbine capacity with a 25 percent capacity factor could only be relied upon to produce energy at a rate of about 25 MW during a year. To get an estimate of the total amount of energy generated per year you would multiply $25 \mathrm{MW}$ by 8,760 (the number of hours in a year), which would be 219,000 MWh. For context, that would supply the yearly energy usage of about 20,000 average homes if it were available 24 hours per day for the year.

"Capacity" in reference to a generating station or project is the electrical power output capability rating of the generator or project, usually expressed in MW. When used in reference to transmission lines, the Capacity is expressed in $\mathrm{kV}$ (thousand volts). So a $235 \mathrm{kV}$ line would have a nominal operating voltage of 235,000 volts. The transfer capacity of a line is a complex calculation that would not be useful to explore here. It is determined by the transmission provider by 
means of an engineering study and depends upon the resources and loads connected to the line.

"Commercial Operation Date (COD)" is the date the project is placed in regular service. It is usually the trigger for the commencement of capacity payments and for the obligations of the project to deliver capacity and energy in the quantities specified in the PSA.

"Curtailment" is the term for shutting down or operating the project at a reduced output. It also refers to limitations or outages on the transmission system over which the project's power will be delivered. The curtailment may be required for maintenance or by problems with equipment or weather. It is important to the parties because it may excuse the customer's obligation to pay for capacity that is unavailable during the curtailment and means that less energy can be delivered, which results in reduced energy payments to the project.

"EISA" is the Energy Independence and Security Act (EISA) of 2005

"Energy" is the electrical energy delivered by a generator or project, usually expressed in megawatt hours or kilowatt hours (MWh or kWh).

"EPC" is an engineering, procurement and construction contract. This is a contract to design and construct a project on a "turn key" basis.

"FERC" is the Federal Energy Regulatory Commission which regulates wholesale interstate energy transactions and hydroelectric projects, among other things, and the rates and terms of service for interstate power transmission.

"Forced Outage" is similar to curtailment except that it is always the result of equipment or other critical failure. A certain low level of forced outages may be assumed as part of the risk each party takes, but this is not always the case. If there are frequent forced outages it might be cause for termination of the PSA. There may be considerable negotiation around when a forced outage is the result of 
a force majeure event (see discussion of this term below) because that would allow the project to avoid being in breach of its delivery obligation. The customer will be reluctant to give up its rights to the project's capacity and energy and may argue either that the project cover any delivery shortfalls at the project's expense or be in breach of the PSA and liable for damages. Obtaining capacity and energy on short notice can be difficult or impossible and almost certainly will be more expensive (though not always) than deliveries from the project.

"Force Majeure" is an event that is beyond the control of a party to a contract that prevents the performance of their obligations under the contract. Common examples of force majeure events are earthquakes, major storms that cause significant damage, explosions, tornadoes and fires, as well as the resulting disruption to transportation and commerce.

"Megawatt" or (MW) is one million watts; a kilowatt (kW) is a thousand watts. These units of electrical capacity are most frequently encountered in the measure of the output capability of generating equipment.

"Megawatt Hour or Kilowatt Hour" is the measure of energy delivered and used over time. In these cases, the delivery of a million or a thousand watts over an hour. It is important to remember that electricity is an instantaneous product - it cannot be generated unless there is a load connected and using it.

“OASIS" is a FERC-regulated transmission provider's Open Access Same Time Information System.

"Power" is often used as a more generic term for the output of a project, but it is more accurately the capacity and energy available from a generating station.

\footnotetext{
"PSA" is a power sales agreement.
} 
"PTC" is a production tax credit. These are available for the output of wind and certain other projects and provide a tax credit for every qualifying $\mathrm{kWh}$ produced by the project for a set period of time - currently set at ten years for wind projects.

"REC" is a renewable energy certificate. There are several organizations that issue these certificates, including the Bonneville Environmental Foundation. In much of the Western United States, these are administered for utilities by the Western Renewable Energy Generation Information System (WREGIS). WREGIS is an independent, renewable energy tracking system for the region covered by the Western Electricity Coordinating Council (WECC). WREGIS tracks renewable energy generation from generators that register in the system using verifiable data and creates RECs for this generation. RECs can be used to monetize the "green" nature of the energy produced, verify compliance with state and provincial regulatory requirements (Renewable Portfolio Standards, for example) and as tools in voluntary market programs.

"RPS" are renewable portfolio standards. These are standards set by utility regulators that require providers to have a minimum percentage of renewable resources in their supply portfolio.

"Volt" or "Voltage" is as the value of the voltage across a conductor when a current of one ampere dissipates one watt of power in the conductor. Voltage is analogous to pressure (which for water is expressed in pounds per square inch).

"Watt" is the product of voltage times amperage and is a measure of the work done by the electric current. So a 1,000 watt bulb puts out more light than a 500 watt bulb. 

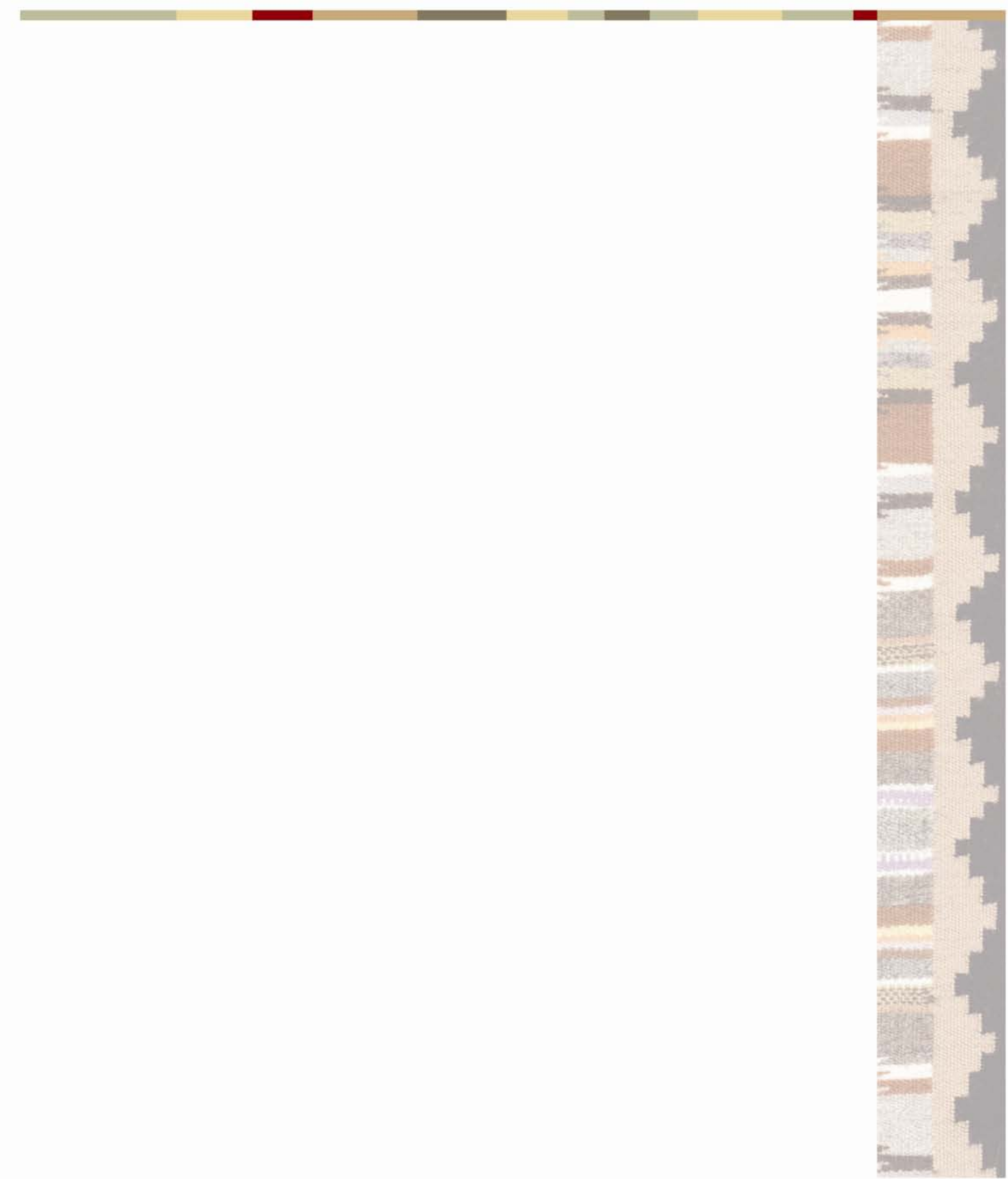


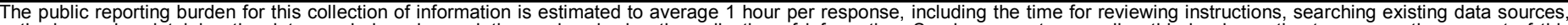

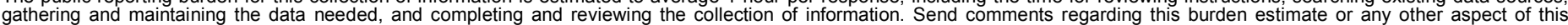

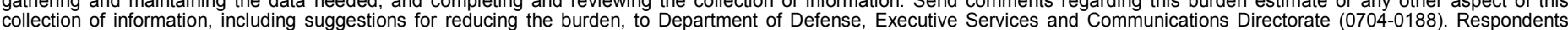

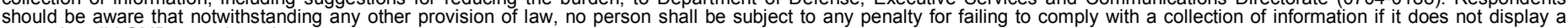

currently valid OMB

PLEASE DO NOT RETURN YOUR FORM TO THE ABOVE ORGANIZATION.

\section{REPORT DATE (DD-MM-YYYY) June 2010 \\ 2. REPORT TYPE \\ Subcontract Report}

4. TITLE AND SUBTITLE

Renewable Energy Development in Indian Country: A Handbook for Tribes
3. DATES COVERED (From - To) 5a. CONTRACT NUMBER

DE-AC36-08GO28308

5b. GRANT NUMBER

6. AUTHOR(S)

Douglas C. MacCourt, Chair, Indian Law Practice, Ater Wynne LLP

5d. PROJECT NUMBER

NREL/SR-7A2-48078

5e. TASK NUMBER

IGTR.8002

5f. WORK UNIT NUMBER

7. PERFORMING ORGANIZATION NAME(S) AND ADDRESS(ES)

Ater Wynne LLP

1331 NW Lovejoy St., Suite 900

8. PERFORMING ORGANIZATION REPORT NUMBER

Portland, OR 97209

9. SPONSORING/MONITORING AGENCY NAME(S) AND ADDRESS(ES)

National Renewable Energy Laboratory

1617 Cole Blvd.

Golden, CO 80401

AEK-9-88294-01

12. DISTRIBUTION AVAILABILITY STATEMENT

National Technical Information Service

U.S. Department of Commerce

5285 Port Royal Road

Springfield, VA 22161

\section{SUPPLEMENTARY NOTES}

NREL Technical Monitor:

14. ABSTRACT (Maximum 200 Words)

This handbook is an accessible reference for those who are new to tribal energy project development or who seek a refresher on key development issues as they navigate the project development process. Building upon the wealth of feedback and experiences shared by tribal and other participants in tribal energy workshops conducted by the National Renewable Energy Laboratory, it is designed to provide tribal leaders, tribal economic and energy enterprises, and those supporting them with a general overview of the renewable energy project development process. It includes information on how to structure a renewable energy project transaction to protect tribal interests, with an emphasis on joint project development efforts undertaken with nontribal parties; a general overview of key energy development agreements, including power sale agreements, transmission and interconnection agreements, and land leases; and a detailed discussion of ways tribes can finance renewable energy projects, the sources of funding or financing that may be available, the types of investors that may be available, and federal tax incentives for renewable energy projects. The guide also includes a glossary of some of the most commonly used technical terms.

15. SUBJECT TERMS

Tribal Energy Projects; Indian Lands; Renewable Energy Development; tribal power sale agreements; tribal energy transmission and interconnection agreements; tribal land leases for clean energy projects; tribal energy project financing; tribal energy funding; federal tax incentives for tribal renewable energy projects

\begin{tabular}{|c|c|c|c|c|}
\hline \multicolumn{3}{|c|}{ 16. SECURITY CLASSIFICATION OF: } & \multirow{2}{*}{$\begin{array}{l}\text { 17. LIMITATION } \\
\text { OF ABSTRACT } \\
\text { UL }\end{array}$} & \multirow{2}{*}{$\begin{array}{l}\text { 18. NUMBER } \\
\text { OF PAGES }\end{array}$} \\
\hline $\begin{array}{l}\text { a. REPORT } \\
\text { Unclassified }\end{array}$ & $\begin{array}{l}\text { b. ABSTRACT } \\
\text { Unclassified }\end{array}$ & $\begin{array}{l}\text { c. THIS PAGE } \\
\text { Unclassified }\end{array}$ & & \\
\hline
\end{tabular}

19a. NAME OF RESPONSIBLE PERSON

19b. TELEPHONE NUMBER (Include area code) 
DISCLAIMER: Nothing in this handbook should be construed or relied upon as legal or tax advice, and readers are responsible for obtaining such advice from their own legal counsel. Instead, this handbook is intended to serve as an introduction to the general subject of tribal energy project development, from which better informed requests for legal, financial and technical advice can be formulated.

By

Douglas C. MacCourt and Ater Wynne LLP

All rights reserved.

Copyright 2010 by Ater Wynne LLP. No part of this publication may be reproduced, stored in a retrieval system, or transmitted in any form or by any means, electronic, mechanical, photocopying, recording or otherwise, without the prior written permission of Douglas C. MacCourt, Ater W/ynne LLP, dcm@aterwynne.com, or via fax at 503-226-0079. 